
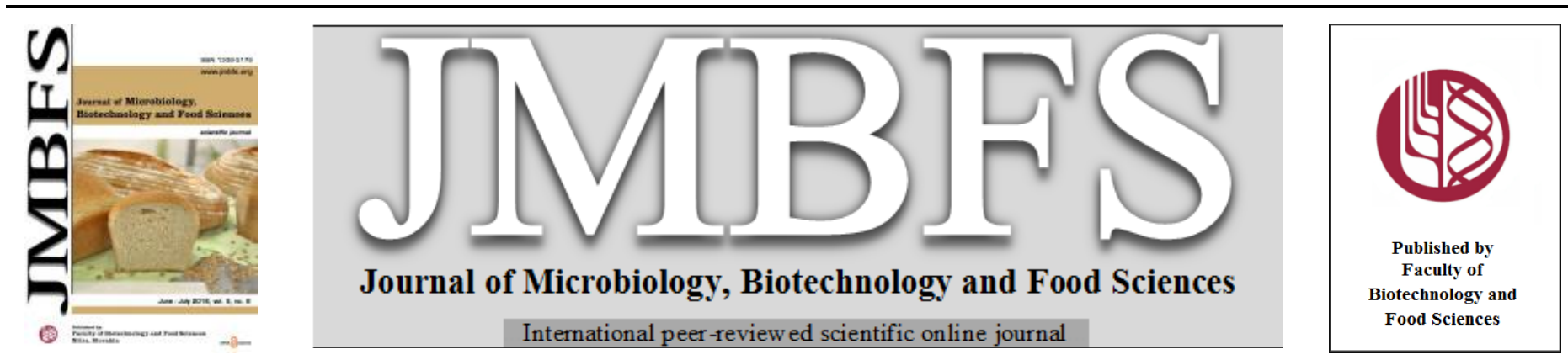

\title{
UTILIZATION OF AGRO-INDUSTRIAL WASTE BY HIGHER MUSHROOMS: MODERN VIEW AND TRENDS
}

\author{
Victor Barshteyn*, Tetiana Krupodorova
}

Address(es): PhD Victor Barshteyn,

Institute of Food Biotechnology and Genomics of the National Academy of Sciences of Ukraine, Osipovskogo 2a, 04123, Kyiv, Ukraine, tel/fax +38 0444627259

*Corresponding author: barmash14@gmail.com

doi: 10.15414/jmbfs.2016.5.6.563-577

ARTICLE INFO

Received 16. 7. 2015

Revised 24. 12. 2015

Accepted 15. 2. 2016

Published 1. 6. 2016

Review

OPEN $\partial_{\text {ACCESS }}$

\begin{abstract}
Waste management and providing a world population with rich in protein food are two important problems of which the utilization of agro-industrial (agriculture and food industry) waste by higher mushrooms causes the growing interest of researchers around the world. More than 150 individual types of wastes have been investigated last decade as alternative substrates alone or in various compositions (more than 450 substrates) for cultivation of 52 higher mushroom species (about 100 strains) as evidenced by the results of more than 130 considered in the review scientific publications. All waste is used as a basis for substrates and supplements thereto, are characteristic of the respective continent and region of the world. Publications containing biochemical studies of substrates and fungi confirm that fungi are grown in rich in biologically active substances unconventional substrates, provide a rich biochemical composition of fungi compared with conventional substrates (sawdust, straw, etc.). The disadvantage of many publications is the lack of mention of examined fungi strains, whereas studies of various strains of the same fungus in the same substrate show different results. The prospect of the study of agricultural residues utilization by higher mushrooms consists in the investigations of: productivity, biological efficiency of the process, morphological and biochemical indices of cultivated mushrooms, depending on the biochemical parameters of substrates and the process conditions; safety of cultivated mushrooms.
\end{abstract}

\section{INTRODUCTION}

Among the world's major problems - providing a rapidly growing world population with food and waste management, including not least the agroindustrial residues (agriculture and food industry). The aim of FAO's program on the Promotion and development of non-wood forest products (NWFP) is to improve the sustainable use of NWFP in order to improve income-generation and food security, to contribute to the wise management of the world's forests and to conserve their biodiversity. One of the important group of NWFP is mushrooms. The FAO report author (Boa, 2004) did not took into account that world population increased on over 800 million people the last decade and reached 7.25 billion. The planet's climate is changing, and not for the better. Under these conditions, to count on mushroom wildlife resources as food, speaking at the same time about the preservation of biodiversity, is impossible. The problem of protection of the natural mushroom flora can be solved by the artificial cultivation of fungi. Wood waste (sawdust, conifer waste) is the traditional substrate for mushroom cultivation (Stamets and Chilton, 1983; Croan, 2004; Moonmoon et al., 2010; Peng, 2010; Khan et al., 2012). The using of wood waste for mushroom cultivation has two major shortcomings. A number of researchers indicate lower results of cultivation on sawdust and lower nutritional value of mushrooms in comparison with other using agro wastes (Onuoha $\boldsymbol{e t}$ al., 2009; Ukoima et al., 2009; Tripathy et al., 2011; Govindaraju et al,. 2013; Dehariya and Vyas, 2013). Furthermore, many forest trees are toxic and allergenic (Meier, 2013). Among substrates alternative to wood waste Stamets and Chilton (1983) mentioned for spawn making and fruit body production sugarcane bagasse, cereal straw, rye bran, rye grain, wheat bran, wheat grain, farm yard manure and some others. Meanwhile, the growth of agricultural waste in the last decades of the XX century, have attracted the researchers attention to this type of potential cheap substrates for the cultivation of mushrooms. Numerous studies have been summarized by Poppe (2000). More than 150 kinds of wastes have been proven to be useful for 45 mushroom species growing. But some listed wastes can be re-divided into at least 100 individual types of wastes. In his next worldwide survey on waste that can be used as a substrate in the Oyster mushrooms cultivation Poppe (2004) named near 90 residues (not only agro-industrial, but some forestry and industrial). In some cases, was noted the possibility of cultivation the other species of fungi in this or that waste. Last decade the situation with the aforementioned important world problems worsened. The number of undernourished and hungry people has not decreased but at the same time one third of food produced for human consumption is lost or wasted globally - a total 1.3 billion tons a year (European Commission. Press release, 2014).

Hundreds of studies devoted to the cultivation of mushrooms on agricultural waste have been carried out, but their ordering and review was not conducted. Mane et al. (2007) presented an overview of 26 substrates reported to be useful for the cultivation of various Pleurotus species (only 8 - in publications after 2000), 8 substrates and 44 combinations of these substrates and 3 additives for $P$. sajor-caju cultivation. The basic plant substrates that can be used for Pleurotus spp. cultivation are sawdust, wheat straw, rice husk, Mango, Jackfruit, Coconut, hulls, straw, stalk , paper, corn cobs, waste cotton, leaves and pseudo stem of banana, water hyacinth, duck weed, rice straw etc. (Josephine, 2015). Minireview by Kulshreshtha et al. (2014) devoted to the achievement and current status of mycoremediation technology based on mushroom cultivation ( 7 species) for the remediation of waste and also focused on the safety aspects of mushroom cultivation on waste. Thus, the analysis of publications, identification of trends and prospects of utilization of agricultural waste by higher mushrooms is relevant and important. Publications (Table) should be divided into three categories. Some researchers explored primarily yield, biological efficiency (BE) and morphological parameters of fungi. Of great interest is the analysis of the biochemical composition of the substrates and mushrooms grown on them, the definition of therapeutic activity of fungi, depending on the substrate. The use of food processing waste is separate important problem.

\section{YIELD, BIOLOGICAL EFFICIENCY AND MORPHOLOGICAL PARAMETERS OF MUSHROOMS}

Agaricus bisporus is the largest commercially produced mushroom in the world Ram and Kumar (2010) investigated morphological parameters of A. bisporus fruiting bodies (initiation of pin heads, harvesting of flushes, diameter and weight of fruit bodies), total yield in cultivation on different agricultural waste. Six mixture formulations were used as substrate for studies (Table 1) Maximum weight of sporophore was obtained with application of casing coconut coir pith + vermi compost + sand, where maximum length of stalk was recorded from coconut coir pith + farm yard manure + sawdust casing mixture. The total maximum yield $(1199.99 \mathrm{~g})$ was obtained by the application of coconut coir pith 
+ vermi compost + farm yard manure + sawdust + sand, which differs significantly.

Pleurotus species (Oyster mushrooms) is the second most cultivated edible mushroom in the world. Optimal conditions for $P$. ostreatus growth, yield, biological efficiency (BE) and mushroom size have been studied by a number of authors (Elenwo and Okere, 2007; Pathmashini et al., 2008; Kumari and Achal, 2008; Nwokoye et al., 2010; Samuel and Eugene, 2012; Oseni et al., 2012; Govindaraju et al., 2013; Yang et al., 2013; Ashrafi et al., 2014; Mohammed et al., 2014). Two crops of $P$. ostreatus were grown on rice straw as the basic substrate. In crop I, rice straw was mixed at spawning with $0 \%, 25 \%$, $50 \%, 75 \%$ and $100 \%$ of banana leaves or Leucaena leucocephala or maize bran or maize cobs. In crop II, rice straw was supplemented at spawning with $0 \%$, $\%, 2 \%, 3 \%, 4 \%$, and $5 \%$ of sunflower or cotton seed cake. Mushroom yield $(1,040.0 \mathrm{~g})$ and BE $(98.5 \%)$ were greater on a 50/50 mixture of rice straw and banana leaves. Rice straw supplemented with $2 \%$ sunflower seed hulls (yield $=1,087.5 \mathrm{~g}, \mathrm{BE}=103.3 \%$ ) gave similar yield and $\mathrm{BE}$ to rice straw supplemented with $2 \%$ cotton seed hulls (yield $=1,073.8 \mathrm{~g}, \mathrm{BE}=101.8 \%$ ), and were significantly greater than other supplement ratios. The largest mushrooms $(21.0$ g) were obtained from non-supplemented rice straw (Mamiro and Mamiro 2011). Three strains of $P$. eryngii such as Pe- 1 (native to Bangladesh), $\mathrm{Pe}-2$ (germplasm collected from China) and Pe-3 (germplasm collected from Japan) were cultivated on sawdust and rice straw and their growth and yield parameters were investigated (Moonmoon $\boldsymbol{e t}$ al., 2010). Pe-1 on sawdust showed the highes biological yield and BE $(73.5 \%)$ than other strains. Also, the mycelium run rate and number of fruiting bodies were higher in Pe-1 than other two strains. The quality of mushroom strains was near about similar. On sawdust, the yield and efficiency were better than those cultivated on rice straw, however, on straw the mushroom fruiting bodies were larger in size.

$P$. florida cultivation on different substrate compositions has been investigated by Mondal et al., (2010) Highest mycelium running rate was found on banana leaves and rice straw (1:1) but the lowest in control. Completion of mycelium running time was lowest on banana leaves and rice straw (1:3 and 3:1). Number of total primordia and effective primordia, found highest in control but the maximum pileus thickness was measured from rice straw. Highest biological yield and economic yield (164.4 $\mathrm{g}$ and $151.1 \mathrm{~g}$ ) was obtained from rice straw which was much higher than control. A number of papers devoted to the study of the process of $P$. pulmonarius cultivation on different mixtures of cotton waste and cassava peel (Adebayo et al. 2009), cotton waste alone and combined with rice husk (Khan $\boldsymbol{e}$ al., 2010), coir fibre, oil palm waste, sawdust of Gmelina arborea and rice straw (Jonathan et al., 2013). P. pulmonarius was also cultivated on agricultura wastes viz., cotton, rice straw, corn cob, corn husk and sawdust (S). Rice bran was added as a nutritional supplement to each substrate. Data collected after two weeks of incubation were diameter of the cap (pileus), length of stem (stipe) and dry matter of fruiting body. The dry matter $(32.4 \pm 1.5 \mathrm{~g})$ and pileus $(19.2 \pm 2.4 \mathrm{~cm})$ of fruiting bodies cultivated on cotton waste supplemented with rice bran $(\mathrm{CR})$ was significantly higher while at the same level of significance, the stipe $(18.0 \pm 1.2 \mathrm{~cm})$ for corn husk supplemented with rice bran $(\mathrm{CHR})$ has significance difference compared with other substrates. Supplemented substrates yielded better compared with non-supplemented substrates. CR was the best substrate followed by $\mathrm{CHR}$ while $\mathrm{S}$ was least. In addition to sawdust which is widely used by farmers, cotton waste, corn cob, husk and rice straw are possible agro-waste materials for $P$. pulmonarius production (Adedokun, 2014). Mane et al., (2007) studied the yield and morphological parameters of $P$. sajor-caju fruiting bodies in cultivation on selected agro wastes viz. cotton stalks, groundnut haulms, soybean straw, pigeon pea stalks and leaves and wheat straw, alone or in combinations. Cotton stalks, pigeon pea stalks and wheat straw alone or in combination were found to be more suitable than groundnut haulms and soybean straw for the cultivation. Organic supplements such as groundnut oilseed cake, gram powder and rice bran not only affected growth parameters but also increased yield Mycelial growth, colonization period, primordial initiation, harvesting time, yield, mushroom size and BE of $P$. sajor-caju were assessed on three different substrates namely maize stalk, pea residue (tendrils) and banana leaves with and without supplementation of rice bran and chicken manure. The faster mycelial growth and highest yield (348.13 g) with $87.03 \% \mathrm{BE}$ was obtained from maize stalk with rice bran and second best yield (299.53 g) with $74.88 \%$ BE was recorded from pea residue with rice bran. Among the substrates used, maize stalk appeared best followed by pea residue and banana leaves. Rice bran showed best supplementation for mycelial growth and yield with all substrates (Pokhrel $\boldsymbol{e t}$ al., 2013). Dehariya and Vyas (2013) determined the effect of different agro-wastes viz. soybean straw, wheat straw, paddy straw, sugarcane bagasses, sun flower stalks, maize stalks, domestic waste, used tea leaves, fruit waste, semal flowers, news paper, bamboo leaves, sawdust and their combinations in 1:1 proportion in $P$. sajor-caju cultivation (yield and BE). Soybean straw showed significantly highest yield (with $93.3 \% \mathrm{BE}$ ). Among all the combinations soybean straw + wheat straw showed significantly highest yield (with $87.3 \% \mathrm{BE}$ ). The organic wastes (dry substrates which include maize cob, cassava peelings, plantain peelings and water melon pod) were used in the study of $P$. tuber-regium cultivation. Maize cob (T1) and cassava peelings (T2) supported very abundant mycelial growth and also the development of healthy fruit bodies of the fungus studied. Plantain peelings (T3) and water melon pod (T4) supported abundant and moderate mycelial growth of $P$. tuber-regium respectively but fruit bodies were not developed on them. In all parameters measured fruit bodies produced on $\mathrm{T} 1$ were better than those on T2 except in dry weight (DW). The DW of $P$. tuberregium was $21.8 \mathrm{~g}$ on both $\mathrm{T} 1$ and $\mathrm{T} 2$. The $\mathrm{BE}$ of $P$. tuber-regium produced on T1 were $8.7 \%$ and $8.5 \%$ on T2. Corn cobs and cassava peelings which are major agro wastes abundantly found in Nigeria, have been found to excellently support the mycelial growth and fruit body formation of $P$. tuber-regium (Stanley and Odu, 2012). The powerful enzyme system of Pleurotus spp. promotes biodegradation of the wide spectrum of substrates, not only traditional sawdust and cereal straw (Table). The increasing interest in Pleurotus spp. mushrooms is explained also of their species diversity.

The influence of seven oak-wood sawdust substrates (OS), supplemented with wheat straw (WS) or corn-cobs (CC) on mycelium growth and sporophore production characteristics of Lentinula edodes (popular edible mushroom) was examined by Philippoussis et al., (2004). Colonization rate measurements demonstrated faster colonization on OS supplemented with WS or CC in a ratio of 1:2 (OS : supplements). Similarly, higher sporophore yields were obtained on $\mathrm{OS}+\mathrm{CC}$ mixtures, especially in the supplementation ratios 1:1 and 1:2. However, substrates with high OS content (2:1 ratio) appeared to promote mushroom quality and high protein content of the sporophores. L. edodes cultivation on hard wood sawdust, rice straw, crushed corn cobs and crushed bagasse supplemented with $20 \%$ wheat bran, $1 \%$ soy bean flour, $2 \%$ gypsum has been investigated by Hassan (2011). Incubation period, early of harvesting, yield and BE were estimated as well as drying parameters for fruit bodies. Sawdust recorded the shortest incubation time and first harvesting day time, while bagasse showed the longest ones. Also, sawdust produced the maximum yield $297 \mathrm{~g} / \mathrm{kg}$ wet media with the highest BE, while bagasse recorded the lowest values.

Pani (2012) studied the utilization of cotton wastes and sunflower stalks either alone or in combination with paddy straw $(1: 3,1: 1,3: 1)$ for sporophore production of milky mushroom, Calocybe indica. The various combinations with paddy straw showed better results (BE) than single substrates (cotton wastes and sunflower stalks). There was also faster substrate colonization and primordial initiation and higher number of fruiting bodies. Cotton wastes + paddy straw (1:3) sustained the highest mushroom yield (73.2 \% BE) which was statistically at par with paddy straw $(71.3 \% \mathrm{BE})$.

Akavia et al., (2009) investigated the cultivation of five Hypsizygus marmoreus strains on 24 substrates (Table 1). Average number of colonized particles per day, $\mathrm{BE}$, number of mushrooms and weight of mushrooms harvested during one month have been studied. The best substrate in terms of BE was corn cob with bran and olive press cake, with a BE of $85.6 \%$. The BE of the same composition but without olive press cake was only $67.5 \%$.

Harvesting yield and BE of Pholiota nameko utilization of different substrates viz. Eucalyptus shaving, Cordia shaving, coffee husk, Pinus shaving, cotton seed and teff straw have been studied by Gizaw (2010). Wheat bran was used as an additive material 100:10 and 100:30 w:w of the main material. Eucalyptus shaving supplemented with $30 \%$ wheat bran showed the best result (yield = $797.33 \mathrm{~g}, \mathrm{BE}=53.27 \%$ ).

The effect of $\mathrm{pH}$ and temperature variations on the growth of Volvariella volvacea cultivated on various agricultural wastes singly and in various combinations has been studied by Akinyele and Adetuyi (2005). A pH range of 5.5 to 8.5 recorded the maximum mycelia yield and the highest mycelia weight was recorded at $\mathrm{pH}$ 6.5. High mycelia growth of the mushroom was also observed between $25^{\circ} \mathrm{C}$ and $30^{\circ} \mathrm{C}$ with the highest mycelia DW of $80.0 \mathrm{mg}$ obtained at $30^{\circ} \mathrm{C}$. Effect of different substrates on mycelial growth and yield of Volvariella spp. (V. diplasia and $V$. volvacea) was also evaluated (Tripathy et al., 2011). Paddy straw, oil palm fibre, sawdust, and a mixture of oi palm fibre and sawdust were screened for the cultivations of $V$. volvacea. The paddy straw served as the control as it is the traditional substrate for the growth of this mushroom. The straw naturally supported the mycelial growth and production of fruit bodies. Growth and production of fruit bodies on oil palm fibre was similar to that of paddy straw. The production of fruit bodies on the mixture of oil palm fibre and sawdust was scanty. Sawdust alone as a substrate produced few fruit bodies that were comparatively small in size (Onuoha $\boldsymbol{e t}$ al. 2009). $V$. volvacea showed that it is an active agro waste bio-destructor, not only the traditional for this fungus paddy straw.

Researchers are interested not only in Pleurotus spp. and Volvariella spp. fruit bodies (first of all) cultivation on cheap substrates, but also in best-known and very delicious edible mushrooms, such as Agaricus spp., Lentinus spp., Hypsizygus marmoreus. 
Table 1 Utilization of agro-industrial waste by higher mushrooms

\begin{tabular}{|c|c|c|c|}
\hline Fungal species & $\begin{array}{l}\text { Wastes and some non waste components (if they } \\
\text { are basic for substrates or control in studies) }\end{array}$ & Best results & References \\
\hline $\begin{array}{l}\text { Agaricus bisporus } \\
\text { (J.E. Lange) Imbach }\end{array}$ & $\begin{array}{l}\text { mung bean straw; beet pulp } \\
\text { coconut coir pith; farm yard manure; sawdust; vermi } \\
\text { compost (wheat straw, wheat bran, urea, potassium, } \\
\text { phosphorus, gypsum molasses and lindane); sand } \\
\text { rice straw; rice bran; chicken manure }\end{array}$ & $\begin{array}{l}\text { mung bean straw }(\text { yield }=2.56 \mathrm{~kg} / 10 \mathrm{~kg}) \\
\text { coconut coir pith }+ \text { vermi compost }+ \\
\text { farm yard manure }+ \text { sawdust }+ \text { sand } \\
\qquad(1: 1: 1: 1: 1) \\
* * *\end{array}$ & $\begin{array}{l}\text { (Al Abttan et al., 2005) } \\
\text { (Ram \& Kumar, 2010) } \\
\text { (Peng, 2010) }\end{array}$ \\
\hline $\begin{array}{l}\text { Agaricus bitorquis } \\
\text { (Quel.) Sacc. }\end{array}$ & rice straw; rice bran; chicken manure & $* * *$ & (Peng, 2010) \\
\hline $\begin{array}{l}\text { Agaricus flocculosipes } \\
\text { R.L. Zhao, Desjardin, } \\
\text { J. Guinberteau \& K.D. Hyde }\end{array}$ & wheat straw +horse manure & yield $=1.04 \mathrm{~g} / \mathrm{kg}$ & (Thongklang et al., 2014) \\
\hline Agaricus subrufescens Peck & wheat straw +horse manure & yield $=85.90 \mathrm{~g} / \mathrm{kg}$ & (Thongklang et al., 2014) \\
\hline $\begin{array}{l}\text { Agrocybe aegerita } \\
\text { (V.Brig.) Singer }\end{array}$ & $\begin{array}{c}\text { wheat straw; cocoa shells; wheat straw } \\
\text { supplemented with either cocoa shells }(17 \%) \text {, citrus } \\
\text { pellets }(17 \%) \text {, carrot mesh }(17 \%) \text { or black tea } \\
\text { pomace }(17 \% \text { and } 45 \%)\end{array}$ & $\begin{array}{c}\text { wheat straw supplemented with black } \\
\text { tea pomace }(17 \% \text { and } 45 \%) . \mathrm{BE}=36 \\
\%\end{array}$ & (Kleofas et al., 2014) \\
\hline $\begin{array}{l}\text { Agrocybe cylindracea } \\
\text { (DC.) Maire }\end{array}$ & $\begin{array}{c}\text { rice bran; wheat bran } \\
\text { wheat straw; two-phase olive mill waste; composted } \\
\text { two-phase olive mill waste }\end{array}$ & $\begin{array}{c}* * * * \\
\text { wheat straw }+20 \% \text { composted two- } \\
\text { phase olive mill waste } \\
(\text { yield }=377.91 \mathrm{~g})\end{array}$ & $\begin{array}{l}\text { (Peng, 2010) } \\
\text { (Zervakis et al., 2013) }\end{array}$ \\
\hline $\begin{array}{l}\text { Antrodia cinnamomea } \\
\text { T.T. Chang \& W.N. Chou }\end{array}$ & $\begin{array}{l}\text { citrus peel (pomelo, lemon, orange and grapefruit) } \\
\text { extracts }\end{array}$ & lemon peel extract & (Yang et al., 2012) \\
\hline $\begin{array}{l}\text { Auricularia auricula-judae } \\
\text { (Bull.) Quél. }\end{array}$ & dry olive mill residue & $\begin{array}{c}\text { increases peroxidase secretion and } \\
\text { produced a sharp decrease in total } \\
\text { phenolic content }\end{array}$ & (Reina et al., 2013) \\
\hline $\begin{array}{l}\text { Auricularia fuscosuccinea } \\
\text { (Mont.) Henn. }\end{array}$ & $\begin{array}{c}\text { rice bran; wheat bran } \\
\text { substrates alone and in combination }(1: 1) \text { : coir; } \\
\text { shells of cacao; banana leaves }\end{array}$ & $\begin{array}{c}* * * \\
\text { banana leaves (mycelial growth rate }=6 \\
\mathrm{~mm} / \text { day) }\end{array}$ & $\begin{array}{l}\text { (Peng, 2010) } \\
\text { (Carreno-Ruiz et al., } \\
\text { 2014) }\end{array}$ \\
\hline $\begin{array}{l}\text { Auricularia polytricha (Mont.) } \\
\text { Sacc. }\end{array}$ & $\begin{array}{c}\text { sawdust mixed with empty fruit bunches }(50: 50)+ \\
10 \% \text { spent grain; sawdust mixed with oil palm } \\
\text { fronds }(90: 10)+15 \% \text { spent grain and compared to } \\
100 \% \text { sawdust }\end{array}$ & $\begin{array}{c}\text { sawdust mixed with oil palm fronds } \\
(90: 10)+15 \% \text { spent grain }-\mathrm{BE}=288.9 \\
\%\end{array}$ & (Abd Razak et al., 2013) \\
\hline $\begin{array}{l}\text { Auriporia aurea } \\
\text { (Peck) Ryvarden }\end{array}$ & amaranth flour after $\mathrm{CO}_{2}$ extraction & high antiviral activity & $\begin{array}{l}\text { (Krupodorova et al., } \\
\text { 2014b) }\end{array}$ \\
\hline $\begin{array}{l}\text { Bjerkandera adusta (Willd.) P. } \\
\text { Karst. }\end{array}$ & dry olive mill residue & $\begin{array}{c}\text { increases peroxidase secretion and } \\
\text { produced a sharp decrease in total } \\
\text { phenolic content }\end{array}$ & (Reina et al., 2013) \\
\hline $\begin{array}{l}\text { Calocybe indica } \\
\text { Purkay. \& A. Chandra }\end{array}$ & $\begin{array}{c}\text { rice bran; maize powder; wheat bran supplement to } \\
\text { rice straw } \\
\text { ten popular paddy straw varieties of Orissa } \\
\text { cotton wastes and sunflower stalks alone or mixed } \\
\text { with paddy straw }(1: 3,1: 1,3: 1) \\
\text { coir pith; maize straw; paddy straw; sugarcane } \\
\text { bagasse; sugarcane leaves and vettiver leaves } \\
\text { sorghum straw; paddy straw; sugarcane bagasse; } \\
\text { banana leaves } \\
\text { paddy straw; wheat straw; soybean straw; coconut } \\
\text { coir pith; cotton waste; sugarcane bagasse } \\
\text { paddy straw; reeds; banana stem; sugarcane bagasse } \\
\text { milled and crushed; sugarcane leaves; coir pith; } \\
\text { sorghum husk; sunflower stem }\end{array}$ & $\begin{array}{l}30 \% \text { maize powder supplement to rice } \\
\text { straw (biological yield }=459.3 \mathrm{~g} / \text { packet) } \\
\text { variety: CR-1014 }(70.5 \% \text { bioefficiency } \\
\text { (BE), Kanchan }(69.9 \% \mathrm{BE}), \\
\text { Jagabandhu }(69.6 \% \mathrm{BE}) \\
\text { cotton wastes + paddy straw }(1: 3) \\
\text { paddy straw (protein }=31.2 \mathrm{~g} / 100 \mathrm{~g}, \\
\text { carbohydrate }=58.4 \mathrm{~g} / 100 \mathrm{~g}), \text { coir pith } \\
\quad(\text { fat }=0.85 \mathrm{~g} / 100 \mathrm{~g}), \\
\text { sugarcane bagasse }(\mathrm{yield}) \\
\text { wheat straw; paddy straw } \\
\text { paddy straw }(\mathrm{BE}=91.81 \%)\end{array}$ & $\begin{array}{l}\text { (Alam et al., 2010) } \\
\text { (Pani, 2011) } \\
\text { (Pani, 2012) } \\
\text { (Lakshmipathy et al., } \\
\text { 2012) } \\
\text { (Ramanathan et al., 2013) } \\
\text { (Vijaykumar et al., 2014) } \\
\text { (Karuppuraj et al., 2014) }\end{array}$ \\
\hline $\begin{array}{l}\text { Coprinellus radians (Desm.) } \\
\text { Vilgalys, Hopple \& Jacq. } \\
\text { Johnson }\end{array}$ & dry olive mill residue & $\begin{array}{c}\text { increases peroxidase secretion and } \\
\text { produced a sharp decrease in total } \\
\text { phenolic content }\end{array}$ & (Reina et al., 2013) \\
\hline $\begin{array}{l}\text { Coprinus comatus } \\
\text { (O.F. Müll.) Pers. }\end{array}$ & $\begin{array}{c}\text { rice bran; wheat bran } \\
\text { spent of } P . \text { sajor-caju, P.ostreatus and P.florida } \\
\text { mixed with } 100 \mathrm{~g} \text { of } \\
\text { the different enrichment types (corn grit, rice grit } \\
\text { and rice bran) }\end{array}$ & $\begin{array}{c}\text { spent of } P . \text { sajor-caju mixed with } 100 \mathrm{~g} \\
\text { of corn grit } \\
(\text { yield }=11.06 \mathrm{~g})\end{array}$ & $\begin{array}{l}\text { (Peng, 2010) } \\
\text { (Dulay et al., 2014) }\end{array}$ \\
\hline $\begin{array}{l}\text { Flammulina velutipes (Curtis) } \\
\text { Singer }\end{array}$ & $\begin{array}{c}\text { rice bran; wheat bran } \\
\text { paddy straw; palm empty fruit bunches; palm- } \\
\text { pressed fiber }\end{array}$ & $\begin{array}{c}\text { *** } \\
\text { paddy straw }+ \text { palm empty fruit bunches } \\
(25: 75) . \mathrm{BE}=185.09 \% \\
\end{array}$ & $\begin{array}{l}\text { (Peng, 2010) } \\
\text { (Harith et al., 2014) }\end{array}$ \\
\hline $\begin{array}{l}\text { Fomes badius } \\
\text { Cooke }\end{array}$ & coffee pulp & $\begin{array}{c}\text { cellulose degradation }(61.3 \%) \\
\text { hemicellulose degradation }(51.2 \%)\end{array}$ & (Parani \& Eyini, 2010) \\
\hline $\begin{array}{l}\text { Fomes fomentarius } \\
\text { (L.) Fr. }\end{array}$ & amaranth flour after $\mathrm{CO}_{2}$ extraction & high antiviral activity & $\begin{array}{l}\text { (Krupodorova } \text { et al., } \\
\text { 2014b) }\end{array}$ \\
\hline
\end{tabular}




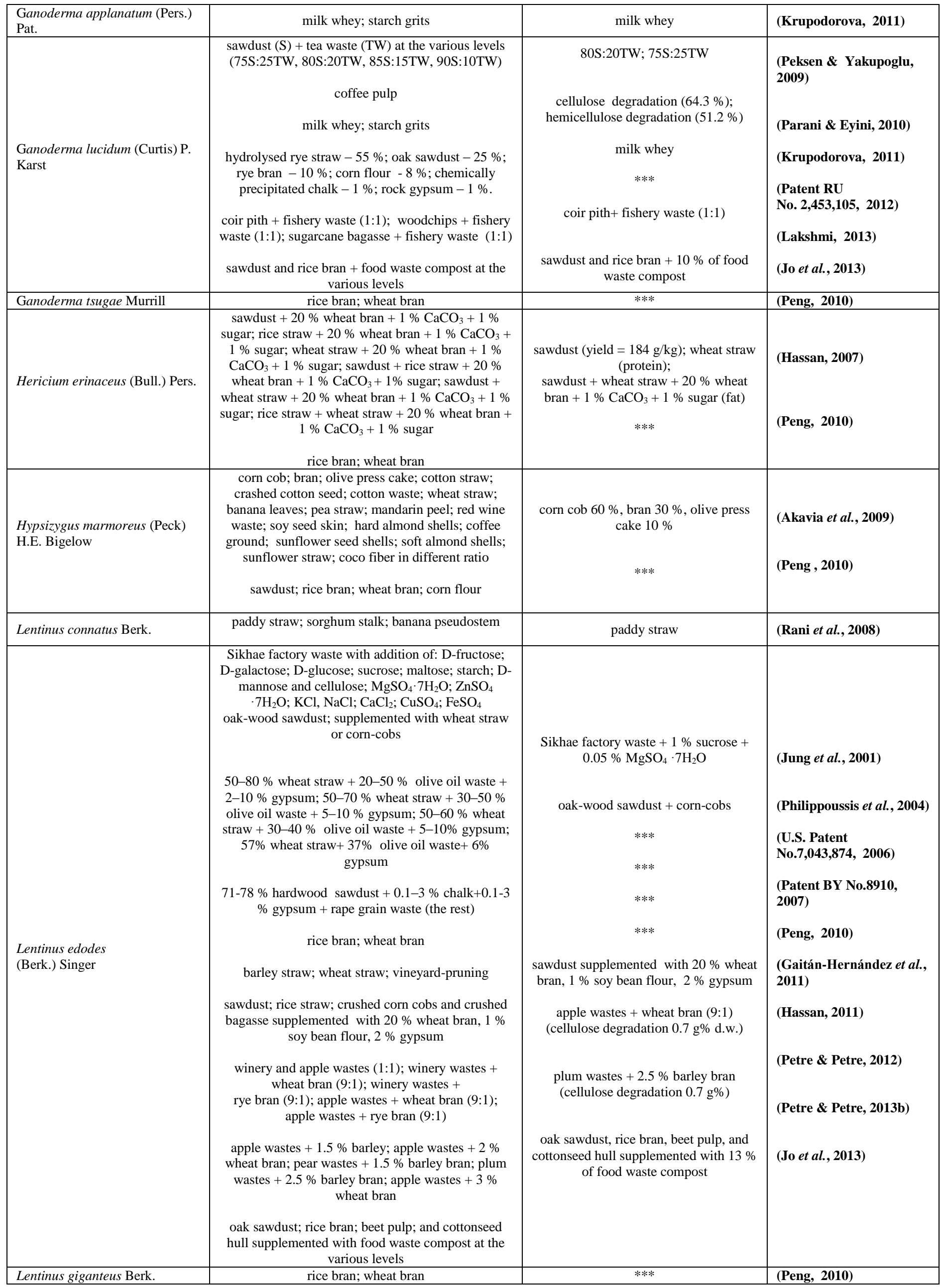




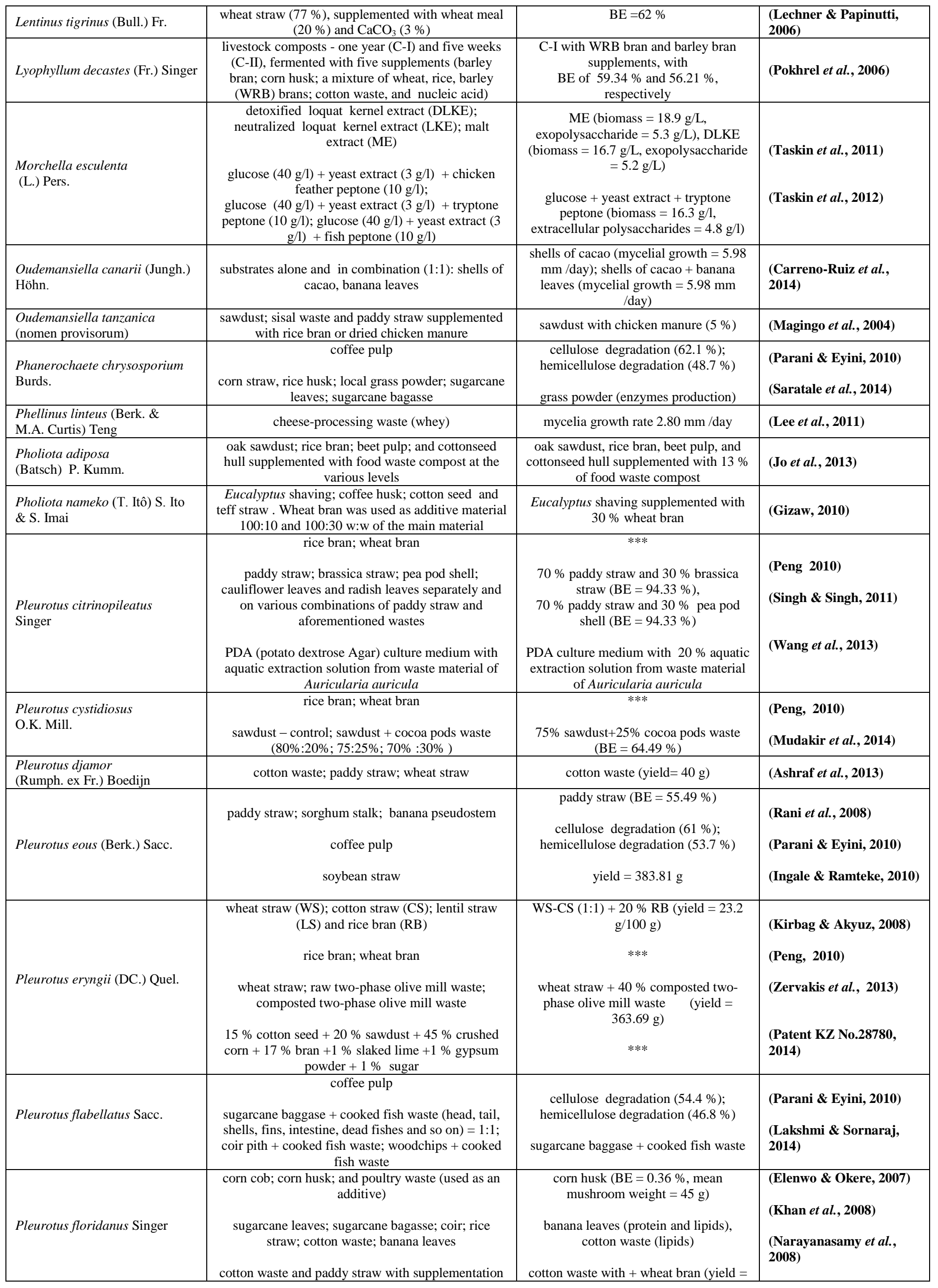




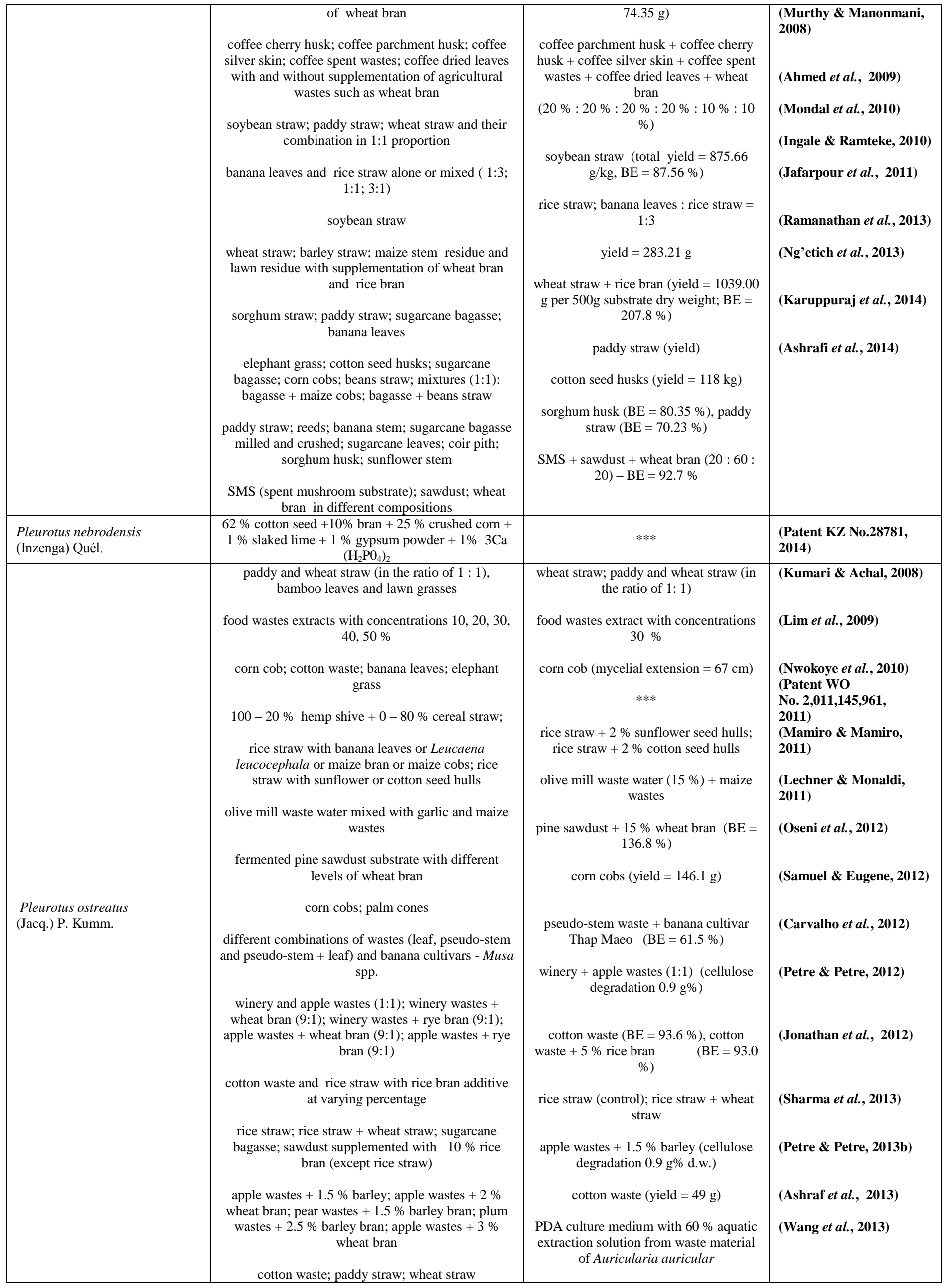




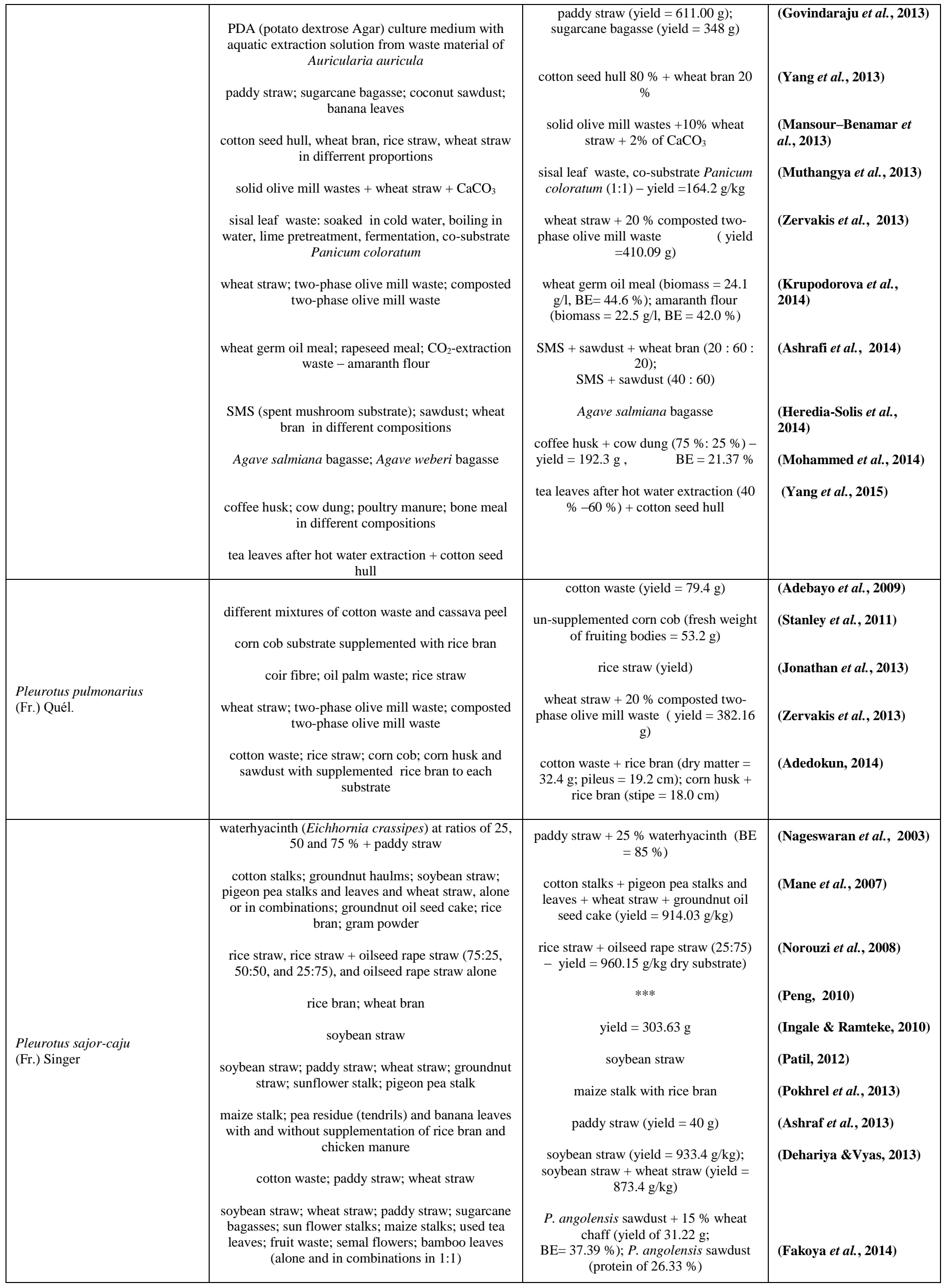




\begin{tabular}{|c|c|c|c|}
\hline & $\begin{array}{c}\text { Pycnanthus angolensis sawdust supplemented with } \\
0,5,10,15, \text { and } 20 \% \text { palmkernel cake, oil } \\
\text { palmfibre, rice bran, wheat chaff, and corn cobs }\end{array}$ & & \\
\hline $\begin{array}{l}\text { Pleurotus sapidus } \\
\text { Sacc. }\end{array}$ & $\begin{array}{c}\text { sisal leaf waste: soaked in cold water, boiling in } \\
\text { water, lime pretreatment, fermentation; co-substrate } \\
\text { Panicum coloratum }\end{array}$ & $\begin{array}{l}\text { sisal leaf waste, co-substrate Panicum } \\
\text { coloratum }(1: 1) \text { - yield }=156.4 \mathrm{~g} / \mathrm{kg}\end{array}$ & (Muthangya et al., 2013) \\
\hline $\begin{array}{l}\text { Pleurotus tuber-regium } \\
\text { (Fr.) Singer }\end{array}$ & $\begin{array}{l}\text { corn cob; corn husk; poultry waste (used as an } \\
\text { additive) } \\
\text { fermented sawdust; oil palm fruit fibre; mixtures } \\
\text { (1:1): oil palm fruit fibre+fermented sawdust; corn } \\
\text { waste+ fermented sawdust; millet waste +fermented } \\
\text { sawdust } \\
\text { maize cob; cassava peelings; plantain peelings; } \\
\text { watermelon pod }\end{array}$ & $\begin{array}{c}\text { corn cob }(\mathrm{BE}=0.67 \%, \text { mean } \\
\text { mushroom weight }=118.9 \mathrm{~g}) \\
\text { corn waste }+ \text { fermented sawdust; millet } \\
\text { waste }+ \text { fermented sawdust } \\
\text { maize cobs (yield }=28 \mathrm{~g}) ; \text { cassava } \\
\text { peelings (yield }=28 \mathrm{~g})\end{array}$ & $\begin{array}{l}\text { (Elenwo \& Okere, 2007) } \\
\text { (Olufokunbi \& Chiejina, } \\
\text { 2010) } \\
\text { (Stanley \& Odu, 2012) }\end{array}$ \\
\hline Schizophyllum commune Fr. & $\begin{array}{c}\text { coconut water } \\
\text { breadcrumb } \\
\text { sunflower seed hull without and with } \\
\text { \%) or 1 \% vegetal oils } \\
\text { supplementation with either wheat bran } 3.75 .5 \\
\text { substrates alone and in combination (1:1): coir, } \\
\text { shells of cacao, banana leaves }\end{array}$ & $\begin{array}{c}\text { coconut water (production of } \\
\text { schizophyllan at } 7.71 \mathrm{~g} / 1000 \mathrm{ml}) \\
\text { mycelial mass }=23.96 \mathrm{~g} / \mathrm{l} \\
\text { sunflower seed hull with } \\
\text { supplementation of } 7.5 \% \text { wheat bran } \\
(\mathrm{BE}=48.3 \%) \\
\text { coir+ shells of cacao (mycelial growth = } \\
9.99 \mathrm{~mm} / \text { day) }\end{array}$ & $\begin{array}{l}\text { (Reyes et al., 2009) } \\
\text { (Ivanova } \text { et al., 2014) } \\
\text { (Figlas et al., 2014) } \\
\text { (Carreno-Ruiz et al., } \\
\text { 2014) }\end{array}$ \\
\hline $\begin{array}{l}\text { Trametes versicolor } \\
\text { (L.) Lloyd }\end{array}$ & $\begin{array}{c}\text { rice bran; wheat bran } \\
\text { breadcrumb } \\
\text { amaranth flour after } \mathrm{CO}_{2} \text {-extraction }\end{array}$ & $\begin{array}{c}\text { *** } \\
\text { mycelial mass }=15.76 \mathrm{~g} / 1 \\
\text { high antiviral activity }\end{array}$ & $\begin{array}{l}\text { (Peng, 2010) } \\
\text { (Ivanova } \text { et al., 2014) } \\
\text { (Krupodorova } \text { et al., } \\
\text { 2014b) }\end{array}$ \\
\hline $\begin{array}{l}\text { Volvariella diplasia } \\
\text { (Berk. \& Broome) Singer }\end{array}$ & $\begin{array}{l}\text { rice bran, wheat bran, rice straw, banana leaf, } \\
\text { sugarcane bagasse supplemented with wheat }\end{array}$ & $\begin{array}{c}50 \% \text { rice bran with } 50 \% \text { wheat }(\mathrm{BE}= \\
12.43 \%)\end{array}$ & (Tripathy et al., 2011) \\
\hline $\begin{array}{l}\text { Volvariella volvacea } \\
\text { (Bull.) Singer }\end{array}$ & $\begin{array}{l}\text { rice husk; rice straw; cotton waste; groundnut shell; } \\
\text { cassava peel; corn cob; oil palm pericarp; red } \\
\text { sorghum shaft and their blends (ratio 1:1) } \\
\text { corn cob; corn husk; poultry waste (used as an } \\
\text { additive) } \\
\text { oil palm fibre; paddy straw (control) } \\
\text { palm fiber; rice husk } \\
\text { cotton waste; rice straw } \\
\text { rice bran; wheat bran; rice straw; banana leaf; } \\
\text { sugarcane bagasse mixed with wheat } \\
\text { paddy straw; cotton waste; banana leaves; corn } \\
\text { stovers; sugarcane baggasse and pulses straw } \\
\text { plantain leaves; maize husk; cotton waste }\end{array}$ & $\begin{array}{c}\text { cotton waste }+ \text { rice husk (mycelia } \\
\text { extension } 101.87 \mathrm{~mm}) ; \text { oil palm } \\
\text { pericarp + groundnut shell }(\text { mycelia } \\
\text { extension } 100.67 \mathrm{~mm}) \\
\text { corn husk }(\mathrm{BE}=0.09 \% \text {, mean } \\
\text { mushroom weight }=16 \mathrm{~g}) \\
\text { oil palm fibre (yield }=16.3 \mathrm{~g}) \\
\text { palm fiber (stipe height }=4.0 \mathrm{~cm}) ; \\
\text { rice husk (pileus diameter }=4.0 \mathrm{~cm}) \\
* * * * \\
50 \% \text { rice bran with } 50 \% \text { wheat }(\mathrm{BE}= \\
13.6 \%) \\
\text { cotton waste (protein }=20.0 \% \text { ) } \\
\text { maize husk (yield = } 24.67 \mathrm{~g} ; \\
\text { carbohydrate, protein, lipids, ash and } \\
\text { fiber ) }\end{array}$ & $\begin{array}{l}\text { (Akinyele \& Adetuyi, } \\
\text { 2005) } \\
\text { (Elenwo \& Okere, 2007) } \\
\text { (Onuoha et al., 2009) } \\
\text { (Ukoima et al., 2009) }\end{array}$ \\
\hline
\end{tabular}

* The substrate names are in accordance with those in the cited publications

** The quantitative measure of the yield is according to the cited publication, although its dimensions were different ( $\mathrm{g}$; $\mathrm{g} / \mathrm{kg}$ of substrate, $\mathrm{g} / 100 \mathrm{~g}$ of substrate, $\mathrm{g} / \mathrm{l} ; \mathrm{etc}$.)

*** The statement of the fact of cultivation, without comparing the results

\section{THE STUDY OF CULTIVATION, PHYSICOCHEMICAL BIOCHEMICAL PARAMETERS OF SUBSTRATES AND MUSHROOMS AND THEIR BIOLOGICAL ACTIVITY}

Al Abttan et al., (2005) studied chemical composition (moisture, carbohydrates, total nitrogen, $\mathrm{C} / \mathrm{N}$, crude fibers, ether extract, ash) of substrates for A. bisporus cultivation. Three wastes (peas, broad bean, beet pulp) were used in different levels with mung bean straw to prepare mushroom growth media. Results indicated that mung bean straw is the best substrate, it is possible to be mixed, but it should not be more than $50 \%$ of the composition of the growth medium which is prepared by mixing with wheat at different levels.

Nutritional values of $P$. ostreatus cultivated on different agricultural wastes studied by a number of authors (Jonathan et al., 2012; Aguilar-Rivera et al., 2012; Bermudez-Savon et al., 2014; Alananbeh et al., 2014), as well as $\mathrm{pH}$ and chemical composition of the substrates also (Amuneke et al., 2011; Carvalho et al., 2012; Aguilar-Rivera et al., 2012; Bermudez-Savon et al., 2014;
Alananbeh et al., 2014). Total ash, fibre, protein, fat, carbohydrate and energy of $P$. ostreatus grown on different substrates as well as yield, size and $\mathrm{BE}$ have been investigated by Sharma et al., (2013). All the substrates (rice straw + wheat straw, rice straw + paper, sugarcane bagasse and sawdust of alder) except rice straw were supplemented with $10 \%$ rice bran. The substrate without supplement was considered as control. Among all aspects, rice straw (control) was found as a best substrate with yield (381.85 g) and BE $(95.46 \%)$ followed by rice + wheat straw, rice straw + paper waste for the production of mushroom. The nutritional composition was also better from mushroom fruit grown on rice straw. Kumari and Achal (2008) studied the effect of paddy straw, wheat straw, mixture of paddy and wheat straw (in the ratio of 1:1), bamboo leaves and lawn grasses on the production of $\quad P$. ostreatus. Wheat straw and a mixture of paddy and wheat straw gave the earliest colonization of fungus. The highest yield was recorded on wheat straw (29.27 $\mathrm{g}$ fresh weight $/ \mathrm{Kg}$ substrate), followed by the combination of paddy and wheat straw $(27.96 \mathrm{~g} / \mathrm{Kg})$. Non-enzymatic antioxidant activities were also obtained by estimating vitamins A, C and E. Significan amount of vitamin $\mathrm{E}$ was found in both fresh $(7.23 \mathrm{mg} / \mathrm{g})$ and dry fruit body (5.93 
$\mathrm{mg} / \mathrm{g}$ ) of $P$. ostreatus. The effect of autoclaved sterilized and non-sterilized substrate on growth and yield of oyster mushroom was examined by Yang $\boldsymbol{e t}$ al. (2013). P. ostreatus was cultivated on rice straw basal substrate, wheat straw basal substrate, cotton seed hull basal substrate, and wheat straw or rice straw supplemented with different proportions $(15 \%, 30 \%$, and $45 \%$ in rice straw substrate, $20 \%, 30 \%$, and $40 \%$ in wheat straw substrate) of cotton seed hull. The non-sterilized substrate did not gave significantly higher mushroom yield and $\mathrm{BE}$ than the sterilized substrate, but some undesirable characteristics, i.e. smaller mushroom cap diameter and relatively long stipe length. Growth, yield, and proximate composition (fat, fibre, ash, protein, carbohydrate) of $P$. sajor-caju cultivated on Pycnanthus angolensis sawdust supplemented with 0, 5, 10,15, and $20 \%$ palm kernel cake, oil palm fibre, rice bran, wheat chaff, and corn cobs have been studied by Fakoya et al., (2014). P. sajor-caju produced maximum yield of $31.22 \mathrm{~g}$ on sawdust supplemented with $15 \%$ wheat chaff. The BE ranged from $6.09 \%$ to $37.39 \%$. Results also showed a maximum crude protein of $26.33 \%$ of $P$. sajor-caju cultivated on sawdust without any supplement and fat content ranging from $0.25 \%$ to $2.21 \%$. Fibre content of harvested mushrooms ranged from $5.05 \%$ to $9.29 \%$. Effect of different substrates on nutritional content of $P$. sajor-caju has been stadied by Patil (2012). P. sajor-caju was cultivated on soybean straw, paddy straw, wheat straw, groundnut straw, sunflower stalk and pigeon pea stalk. Soybean straw showed significantly highest yield $(845.66 \mathrm{~g} / \mathrm{kg})$ and BE with maximum crude protein $(25.33 \%)$ content. Significantly maximum moisture and crude fiber content was recorded on sunflower stalk, i.e. $89.35 \%$ and $7.82 \%$ respectively. Maximum total carbohydrate $(56.00 \%)$ was recorded on wheat straw, while maximum fat and ash content of $P$. sajor-caju was recorded on groundnut straw, i.e. $2.85 \%$ and $7.00 \%$ respectively. Ashraf et al., (2013) studied growth and yield, morphological parameters, chemical composition of three varieties of Oyster mushroom ( $P$. sajor-caju, $P$. ostreatus, and $P$. djamor) grown on three different substrates cotton waste, wheat straw and paddy straw. The fastest spawn running, primordial initiation, harvesting stage, maximum number of fruiting bodies and maximum yield was observed on cotton waste. P. djamor showed the highest percentage of dry matter (17.23\%) and moisture content was found high in $P$. sajor-caju (87.37\%). P. ostreatus and $P$ sajor-caju showed the maximum protein $(27.23 \%)$ and fiber $(26.28 \%)$ contents. The ash contents were found maximum in P. sajor-caju $(9.08 \%)$. The highest fat and carbohydrate contents were found in P. djamor (3.07\% and 37.69 $\%$ respectively). P. citrinopileatus protein, total sugar and non reducing sugar content have been investigated in process of cultivation on paddy straw, brassica straw, pea pod shell, cauliflower leaves and radish leaves separately and on various combinations of paddy straw and aforementioned wastes (Singh and Singh, 2011). The mushroom failed to grow on pea pod shell, cauliflower leaves and radish leaves when it was cultivated separately on these vegetable wastes. However, it grew very well on paddy straw in combination with other substrates. $70 \%$ paddy straw and $30 \%$ other wastes combination supported maximum BE of mushroom followed by $80 \%$ paddy straw and $20 \%$ other wastes combination. The protein content, total sugar and non reducing sugar content was found to be higher in the mushrooms grown on paddy straw and other agro wastes combination than on paddy straw alone. Similarly, six essential amino acids i.e. leucine, isoleucine, valine, threonine, methionine and phenylalanine content was higher in the mushrooms cultivated on paddy straw and other agro wastes combination than on paddy straw alone. Nutritional composition of $P$. florida cultivated on sawdust, sugarcane leaves, sugarcane bagasse, coir, rice straw, cotton waste, banana leaves has been studied by Khan $\boldsymbol{e t}$ al., (2008). The amount of protein found in mushroom cultivated in banana leaves was significantly higher than in any other substrate. $P$. florida was also cultivated on soybean straw, paddy straw, wheat straw and their combination in 1:1 proportion to determine the effect of these agro waste on yield, moisture content, crude protein, total carbohydrates, fat, crude fiber, ash and minerals like $\mathrm{Ca}, \mathrm{P}, \mathrm{Fe}$ content. Soybean straw showed significantly highest yield $(875.66 \mathrm{~g} / \mathrm{Kg}), \mathrm{BE}(87.56 \%)$ with maximum crude protein $(23.50 \%)$ and maximum phosphorus $(920 \mathrm{mg} / 100$ $\mathrm{mg}$ of dry mushroom) content. Maximum moisture $(92.45 \%)$ and crude fiber content $(8.10 \%)$ in the fruiting bodies was recorded on paddy straw cultivation The combination of soybean straw + paddy straw showed significantly highest fat $(2.60 \%)$, calcium $(310 \mathrm{mg} / 100 \mathrm{gm})$ and iron $(13.06 \mathrm{mg} / 100 \mathrm{gm}$ of dry mushroom) content (Ahmed et al., 2009). Jonathan et al., (2013) reported about the yield, mineral elements content and morphological parameters of $P$. pulmonarius cultivated on coir fibre, oil palm waste, sawdust of Gmelina arborea and rice straw at different rice bran level. The most abundant mineral element in P. pulmonarius was $\mathrm{K}(30.20 \mathrm{mg} / 100 \mathrm{~g})$. This was obtained on rice straw at rice bran $10 \%$ concentration; while the least mineral element was $\mathrm{Cu}(0.006 \mathrm{mg} / 100$ g). The highest values of $\mathrm{Ca}$ and $\mathrm{Mg}$ obtained were 3.90 and $2.67 \mathrm{mg} / 100 \mathrm{~g}$ respectively on sawdust (rice bran $10 \%$ ) and palm wastes (rice bran $20 \%$ ). The values of $\mathrm{Fe}$ obtained, varies from 0.007 to $0.12 \mathrm{mg} / \mathrm{g}$ on rice straw (rice bran 10 $\%$ and $40 \%$ ). Manganese has values varying from $0.04 \mathrm{mg} / \mathrm{g}$ to $0.09 \mathrm{mg} / \mathrm{g}$ on coir fibre and oil palm waste with $40 \%$ rice bran. Highest mean stipe length $(6.68 \mathrm{~cm})$ was found in $P$. pulmonarius produced from rice straw while the least mean stipe length $(4.08 \mathrm{~cm})$ was detected on oil palm waste. The highest pileus diameter $(7.08 \mathrm{~cm})$ was found on rice straw while the mean height obtained from the four substrates, were relatively close with values varying between 6.0 and 9.3 $\mathrm{cm}$. Rice straw produced the highest yield with total mean weight of $93.33 \mathrm{~g}$.
Seven different substrates supplemented with fermented sawdust were used to produce mushrooms and sclerotia of $P$. tuber-regium (Olufokunbi and Chiejina, 2010). Protein content ranged from $20.59 \%$ for fermented sawdust substrate to $25.19 \%$ for river sand substrate. The rate of substrate colonization had a significant effect on sclerotium production. The mean dry weight yields varied from $46.26 \mathrm{~g}$ for mixture of rice bran and fermented sawdust substrate to $127.48 \mathrm{~g}$ for fermented sawdust substrate alone. The highest sclerotial protein content $(8.40 \%)$ was from mixture of rice bran and fermented sawdust substrate although it was not significantly different from those of other substrates. A mixture of river sand and fermented sawdust substrate is recommended as the best substrate for the production of $P$. tuber-regium mushrooms while a mixture of corn waste and fermented sawdust substrate is recommended for sclerotial production.

The degradation of lignocellulosic wastes such as paddy straw, sorghum stalk, and banana pseudostem was investigated during solid-state fermentation by edible mushrooms L. connatus and P. eous (Rani et al., 2008). BE of $68.75 \%$ was observed in paddy straw followed by sorghum stalk $(46.67 \%)$ for $L$ connatus and 55.49 was observed in paddy straw followed by sorghum stalk $(45.10 \%)$ for $P$. eous. The activity of extracellular enzymes, namely cellulase, polyphenol oxidase, and laccase, together with the content of cellulose, lignin, and phenols, was studied in spent substrates on seventh, 7th, 17th, and 27th days of spawning, and these values were used as indicators of the extent of lignocellulosic degradation by mushroom. Both the mushroom species proved to be efficient degraders of lignocellulosic biomass of paddy straw and sorghum stalk, and the extent of cellulose degradation was $63-72 \%$ of dry weight (DW), and lignin degradation was $23-30 \%$ of the DW. The chemical changes in barleystraw (BS), wheat-straw (WS) and vineyard-pruning (VP) substrates were determined during colonization of $L$. edodes mycelia in solid state fermentation (Gaitán-Hernández et al., 2011). VP appeared to promote early sporophore initiation. The concentration of hemicellulose in BS and VP decreased gradually from $25.5 \%$ to $15.6 \%$ and from $15.8 \%$ to $12.3 \%$, respectively. However in WS, hemicellulose decreased from $27.2 \%$ to $9.5 \%$. Lignin broke down continuously in BS and WS, with $31.8 \%$ and $34.4 \%$ degradation, respectively; higher than that of cellulose. During the pinning stage, the C:N ratio decreased in VP and BS, but not in WS. On all substrates the phenols decreased notably throughout the first week of mycelial growth. The time elapsed (days) to pinning was positively correlated with cellulose content, total sugar and inversely correlated to lignin and phenol content.

Yield, biological efficiency (BE) and the chemical composition of substrates and fruiting bodies have been investigated in Ganoderma lucidum solid-state fermentation on substrate mixtures with tea waste (TW) supplement (Peksen and Yakupoglu, 2009).

The edible mushroom Oudemansiella tanzanica, which is new to science, has been studied as a potential crop to reduce agricultural solid wastes and increase mushroom production. The substrates sawdust (natural for this mushroom), sisal waste and paddy straw supplemented with chicken manure resulted in the highest biological efficiencies of any mushroom cultivated in Tanzania so far Composition of the substrates and supplements in terms of acid detergent fiber, neutral detergent fiber, lignin, cellulose, hemicellulose, carbon, C:N ratio, nitrogen, crude protein, total solids, volatile solids, $\mathrm{pH}$ and crude fiber, reduction in the components lignin, cellulose, hemicellulose, carbon, nitrogen, crude protein, total solids and volatile solids on studied substrates supplemented with rice bran or chicken manure after growth of Oudemansiella tanzanica have been investigated (Magingo et al., 2004).

Considerable interest of researchers is the study of substrates and mushrooms chemical composition in case of $V$. volvacea cultivation. Akinyele and Adetuyi (2005) investigated the effect of $\mathrm{pH}$ and temperature variations on the growth of $V$. volvacea cultivated on rice husk, rice straw, cotton waste, groundnut shell, cassava peel, corn cob, white afra dust, red afra dust, oil palm pericarp and red sorghum shaft and their blends (ratio 1:1). Nutritional properties of volvacea grown on plantain leaves, maize husk and waste cotton were studied by Adedokun and Akuma (2013). Biochemical analysis of paddy straw, cotton waste, banana leaves, corn stovers, sugarcane baggasse and pulses straw used as substrates was conducted before and after inoculation with the of $V$. volvacea (strain $V v p k$ ). The nitrogen \%age, crude protein, crude fiber and ash contents were estimated in all substrates used for the cultivation of edible fungus, to make the comparison that how much this edible fungus plays role in the enhancement of these estimated contents in all the above mentioned substrates before and after treatment with $V$. volvacea culture. The mean values of the nitrogen percentage of the substrates showed that it was high in the cotton waste (3.80) followed by the pulses straw, paddy straw and sugarcane baggasse and minimum nitrogen was found in the banana leaves. The mean values of the protein percentage of the substrates showed that highest protein was present in the cotton waste $(20.00 \%)$ followed by the corn stover $(10.28 \%)$. The highest crude fiber was found in cotton waste $(42.36 \%)$, followed by the sugarcane baggasse $(39.49 \%)$. The ash contents were high in cotton waste $(22.30 \%)$ followed by the paddy straw $(20.20$ \%) (Ul Haq et al., 2011).

Only a few papers contain a study of heavy metals content in cultivated mushrooms: $\mathrm{Pb}$ (less than acceptable weekly intakes for adults) (Alananbeh $\boldsymbol{e t}$ al., 2014), $\mathrm{Cd}$ and $\mathrm{Pb}$ (the concentrations were under the detection limit of the 
metod used) (Akyüz and Kirbağ, 2010a; Akyüz and Kirbă̆, 2010b), Cd and $\mathrm{Pb}$ (the concentrations of $\mathrm{Cd}$ were under the detection limit of the metod used, the concentrations of $\mathrm{Pb}$ were less than acceptable weekly intakes for adults) (Mallikarjuna et al., 2013). At the same time, the study of wild mushrooms testify to the exceeding of permissible concentrations of heavy metals (Falandysz et al., 2001; Isiloğlu et al., 2001).

Not sufficiently studied remains the question about the effect of substrate on biological activity of fungi. Antibacterial activity of $L$. edodes against Bacillus subtilis was evaluated in cell-free filtrates obtained after growth in 14 differen culture media. The highest $B$. subtilis growth inhibition was promoted by filtrates of growth media supplemented with rice bran, vermiculite or molasses Antibacterial activity, detected between 20 and 24 days of incubation of stationary cultures, was absent in filtrates of aerated cultures. Temperatures of $20-25^{\circ} \mathrm{C}$ enhanced both growth and antibacterial activity. Optimum $\mathrm{pH}$ for $L$. edodes mycelial growth was 3.0-3.5, while for production of antibacterial substance -4.5 . The results indicated that incubation conditions that enhance mycelial growth are quite different from those necessary for production of antibacterial substance(s) by L. edodes (Hassegawa et al., 2005). Ramanathan et al., (2013) studied the antimicrobial activity of ethanol extracts of $P$. florida and $C$. indica cultivated on paddy straw, sugarcane bagasse, sorghum straw and banana leaf. $P$. florida and $C$. indica possessed antimicrobial property against antibiotic resistant human pathogens similar to that of the commercially available antibiotics. Antiviral activity against type A influenza virus of birds $\mathrm{A} /$ chicken/Kurgan/05/2005 (H5N1) and humans A/Aichi/2/68 (H3N2) was investigated (Teplyakova et al., 2012) for aqueous extracts from mycelium of 11 basidial fungi species collected in the Altai Mountains (Altai Republic, Russia). A non-standard substrate (oat-corn water) was used in this study. Higher mushrooms mycelia cultivated on amaranth flour after $\mathrm{CO}_{2}$ extraction (plant waste) have been investigated for antiviral activity in vitro (Krupodorova $\boldsymbol{e t}$ al. 2014b). All 10 investigated mushroom species inhibited the reproduction of influenza virus strain A/FM/1/47 (H1N1) in MDCK cells reducing the infectious titer by 2.0-6.0 lg ID50. Four species, P. ostreatus, Fomes fomentarius, Auriporia aurea, and Trametes versicolor, were also determined to be effective against HSV-2 strain BH in RK-13 cells, with similar levels of inhibition as for influenza.

The half of fungi species from 52 species represented in this review were described as bio-destructors in the last 12 years. Of them, 14 are edible and conditionally edible (Agaricus flocculosipes, Agaricus subrufescens, Agrocybe cylindracea, Auricularia fuscosuccinea, Lentinus connatus, Lentinus giganteus, Lentinus tigrinus, Lyophyllum decastes, Oudemansiella canarii, Oudemansiella tanzanica, Pleurotus djamor, Pleurotus nebrodensis, Pleurotus tuber-regium, Volvariella diplasia), and 7 - medicinal (Antrodia cinnamomea, Auriporia aurea, Fomes fomentarius, Ganoderma applanatum, Ganoderma tsugae, Phellinus linteus, Trametes versicolor).

One of the most important aspects of mushroom cultivation is the rational choice of the substrate. Various substrates and basic compositions were investigated and evaluated in many countries. It is obvious that the investigated substrates affected differently on mycelial growth and fructification, depending on the content of those or other nutrients in substrates and individual requirements of studied species or strains of fungi in nutrients. Some types of agro waste are characteristic for all continents of the Earth: cereal straw, cereal bran, corn, rape rye, soy, sorghum and sunflower wastes, spent mushroom substrate, farm yard manure, chicken manure, livestock composts, vermi compost. Other wastes are characteristic of the respective continent and region of the world. To find new type of waste as a component of substrate is very difficult, therefore, the subject of the most studies mentioned in this review became different combinations of known components of substrates. Some new substrates will be discussed below. The noticeable effect on the increase in mushroom production is explained by the development of the simple techniques of cultivation in the controlled conditions.

\section{UTILIZATION OF FOOD WASTES (MAINLY, AFTER FOOD PROSESSING)}

Food lost or wasted at the stage of processing is (by Region, 2009): North America and Oceania $-9 \%$ (from total lost or wasted food $42 \%$ ), Industrialized Asia $-2 \%$ (from total lost or wasted food $25 \%$ ), Europe $-5 \%$ (from total lost or wasted food $22 \%$ ), North Africa, West and Central Asia - $4 \%$ (from total lost or wasted food $19 \%$ ), Latin America - $6 \%$ (from total lost or wasted food 15 $\%$ ), South and Southeast Asia $4 \%$ (from total lost or wasted food $17 \%$ ), SubSaharan Africa $-7 \%$ (from total lost or wasted food $23 \%$ ) (Lipinski et al., 2013). Significant interest of scientists focused on the ways of food processing waste management.

Sugarcane is the world's largest crop by production quantity. The worldwide harvest is more than 1.8 billion tons. For each 10 tons of sugarcane crushed, a sugar factory produces, after juice extraction, nearly 3 tons of wet bagasse. The high moisture content of bagasse, typically 40 to $50 \%$, is detrimental to its use as a fuel. Due to its typical (on a washed and dried basis) chemical composition (cellulose $=45-55 \% ;$ hemicellulose $=20-25 \%$; lignin $=18-24 \% ;$ ash $=1-4 \%$; waxes $<1 \%$ ) bagasse is of interest as a substrate for mushroom cultivation. Sugarcane baggase and six others agricultural wastes (saw dust, coir, sugarcane leaves, cotton waste, banana leaves and rice straw) were used as substrates or nutrient source for the production of $P$. florida to investigate the nutritional composition of mushroom. The protein content of $P$. florida cultivated on sugarcane baggase was one of the lowest. The amount of protein found in mushrooms cultivated in banana leaves was significantly higher than in any other substrate (Khan et al., 2008). Elephant grass, cotton seed husks, sugarcane bagasse, corn cobs, beans straw, mixture of bagasse + maize cobs (1:1) and bagasse + beans straw (1:1) have been investigated for $P$. florida cultivation The cotton seed husks had the greatest influence on both growth and total yield of $118 \mathrm{~kg}$. It demonstrated excellent mycelia growth, greater height, stem circumference and cap diameter. The total yield on bagasse + beans straw $(1: 1)$ was the second and bagasse - the third (Ng'etich et al., 2013). The BE of $P$. florida cultivation on sugarcane bagasse crushed was $66.66 \%$ (the third result from 9 substrates) and BE of $C$. indica cultivation on sugarcane bagasse milled was $71.20 \%$ (the second from 9 substrates) (Karuppuraj et al., 2014). Selection of different substrates for the cultivation of $C$. indica shows that the lowest yield was recorded in the treatment of sugarcane baggase $(515.7 \mathrm{gm} / \mathrm{kg}$ dry substrate $)$ in comparison with wheat straw (1463 gm/kg dry substrate), soybean straw, coconut coir pith and cotton waste (1261 gm, $1087 \mathrm{gm}$ and $920.7 \mathrm{gm} / \mathrm{kg}$ dry substrate). The BE was appropriate (Vijaykumar et al., 2014). $50 \%$ sugarcane bagasse supplemented with $50 \%$ wheat showed the worst result (yield $=760 \mathrm{~g}$, $\mathrm{BE}=7.6 \%$ ) for $V$. diplasia and third result (from seven substrates) for $V$. volvacea (yield $=960 \mathrm{~g}, \mathrm{BE}=9.6 \%$ ). The best result showed the substrate $50 \%$ rice bran with $50 \%$ wheat for both mushrooms (Tripathy et al., 2011). Sugarcane bagasse showed 7th result (yield $=641.7, \mathrm{BE}=64.1 \%$ ) from 13 substrates for $P$. sajor-caju cultivation (Dehariya and Vyas, 2013). Thus, despite the promising chemical composition, sugarcane bagasse showed rather mediocre results as substrate and additives thereto.

The sugarcane bagasse became the part of mixted substrate (with seafood processing wastes) in two studies. Seafood processing wastes were mixed with selected agro-industrial wastes (e.g., coir pith, woodchips, sugarcane bagasse) in specific ratio (1:1) (Lakshmi, 2013). Not taking into account «control» (sugarcane and coir pith) the highest biological yield ( $23.15 \mathrm{~g} / \mathrm{bed})$ of $\mathrm{G}$. lucidum and BE showed mixture coir pith+ fishery waste $(1: 1)$. This study was continued by the examination of the utilization of seafood processing wastes for artificial cultivation of edible mushroom $P$. flabellatus in laboratory condition (Lakshmi and Sornaraj, 2014). The selected agro-industrial wastes such as coir pith, woodchips and sugarcane bagasse were mixed with cooked fish waste (CFW) in the ratio of 1:1 (500 g:500 g). The substrates which were not mixed with CFW were treated as control. Not taking into account «control» (sugarcane) the highest biological yield $(35.00 \mathrm{~g} / \mathrm{bed})$ of mixture sugarcane baggase + cooked fish waste (1:1)

Worldwide olive oil production is reported to be about 3,200,000 tons for the years 2013/2014. The liquid effluent of olive oil process, the olive mill wastewater (OMWW), amounts to $0.5-1.5 \mathrm{~m}^{3}$ per $1000 \mathrm{Kg}$ of olives. Lechner and Monaldi (2011) examined the use of OMWW at different concentrations for moistening the garlic and maize wastes to produce basidiomes of $P$. ostreatus and to compare with substrate without OMWW. P. ostreatus was cultivated in garlic and maize wastes mixed with 15, 30, 45 and $60 \%$ of OMWW. Bags with $0 \%$ OMWW (control) and $100 \%$ OMWW were also inoculated. The BE $(129.5 \%)$ and the total yield ( $388.5 \mathrm{~g})$ obtained permitted to conclude that the best substrate utilized for $P$. ostreatus production was a mixture composed of OMWW $(15 \%)$ and maize wastes. The effect in the growth of $P$. ostreatus on garlic wetted with 15 and $30 \%$ of OMWW was the same as for control. OMWW is characterized by high degree of organic pollution chemical oxygen demands. D'Annibale et al., (2004) showed that Panus tigrinus and $L$. edodes removed toxic phenols from OMWW. Lakhtar et al., (2010) investigated sixteen strains of $L$. edodes for their tolerance to OMWW, apical growth rate, and biomass production on agar media. The highest biomass yields were recorded in four strains (Le118, Le119, Le121, Le122) grown in the presence of $20 \%$ OMWW. Fifteen fungal strains belonging to five species (Basidiomycota): Agrocybe cylindracea (strains IK10 (Greece), IK21 (Greece), and SIEF0834 (China), P. cystidiosus (strains LGAM P50 (Greece), LGAM P100 (Greece), and D415 (USA), P. eryngii (strains LGAM63 (Greece), LGAM101 (Greece), and UPA10 (Italy), P. ostreatus (strains LGAM60 (Greece), LGAM106 (Greece), and LGM850402 (Hungary), and $P$. pulmonarius (strains LGAM10 (Greece), LGAM26 (Greece), and LGM850403 (France), were evaluated for their efficacy to colonize media composed of twophase olive mill waste (TPOMW), which was used either raw or composted in mixtures with wheat straw in various ratios. Qualified strains exhibited high values of BE (e.g., $120-135 \%$ for Pleurotus spp. and $125 \%$ for A. cylindracea) and productivity in subsequent cultivation experiments on substrates supplemented with $20-40 \%$ composted TPOMW or $20 \%$ raw TPOMW. The substrates hemicellulose content was negatively correlated with mycelium growth rates and yields and positively with earliness; in addition, cellulose: lignin ratio presented a positive correlation with mycelium growth and mushroom weight for A. cylindracea and with earliness for all species examined (Zervakis et al., 2013).

The olive oil production is typical for Mediterranean countries, sunflower, rapeseed and other oilseeds (soybean, amaranth, wheat germ) are typical for East Europe countries. The intensity of $P$. ostreatus biomass accumulation (18-24.1 
g/l) and high conversion of substrates (33.3-44.6\%) have shown prospects for this mushroom cultivation on new substrates such as wheat germ oil meal, $\mathrm{CO}_{2-}$ extraction waste - amaranth flour and rapeseed meal. The optimum concentration of selected substrates were $70 \mathrm{~g}$ in 1 liter of distilled water for wheat germ oil meal and amaranth flour, $60 \mathrm{~g} / \mathrm{l}$ - for rapeseed meal. It was found 17 amino acids, including 9 essential in fungi biomass hydrolyzate. Significant influence of cultivation substrate on quantitative composition of amino acids has been established. To all biomass samples the prevalence of glutamic and aspartic acids, arginine among the nonessential amino-acids, leucine, lysine and cystine among the essential amino-acids were common. Endopolysaccharides content in mushroom biomass and exopolysaccharides in culture liquid were slightly different depending on the selected substrates (Krupodorova et al., 2014a). The content of proteins, lipids, amino and fatty acids was investigated in mycelium and culture broth of medicinal mushrooms Cordyceps sinensis, $P$. ostreatus, and Schizophyllum commune cultivated on amaranth flour (Krupodorova et al., 2012). Seven essential amino acids were present in the proteins of all mushroom samples, with aspartic $(6.34 \%-14.29 \%)$ and glutamic $(15.12 \%-17.51 \%)$ acids predominating in culture mycelium and glutamic acid $(16.3 \%-19.1 \%)$ in culture broth. Lipids in the mycelium of species $C$. sinensis, P. ostreatus, and Sch commune consisted of 10 fatty acids and 12 fatty acids in culture broth in our experiments. Major acids in culture mycelium and culture broth of fungi were linoleic $(42.43 \%-67.41 \%)$, oleic $(10.47 \%-32.54 \%)$, and palmitic (16.43 $\%-20.33 \%)$. The proteins and lipids in culture broth of studied species contained a higher level of total non-essential amino acids and unsaturated fatty acids as compared to those in culture mycelium. Krupodorova and Barshteyn (2012) studied the ability of medicinal and edible mushroom species from different systematic and ecological groups for biotransformation of $\mathrm{CO}_{2}$-extraction (Echinacea purpurea, Humulus lupulus) and food industry (broken vermicelli, flour milling production - grits, confectionery industry - cacao shell) waste. The perspective alternative substrates for 17 mushroom species cultivation have been determined according to biomass accumulation criteria. Sunflower seed hull, an abundant and cheap by-product of the edible oil industry, was used as a substrate for growing $S$. commune (Figlas et al., 2014). Mushroom mycelial growth rate on substrates prepared with sunflower seed hull, in absence or presence of supplements (barley, wheat bran, sunflower or olive oil), was evaluated. The growth analysis on sunflower seed hull $(37.5 \%)$ substrate showed a mycelial run length of $3.8 \mathrm{~cm}$ in seven days. In comparison, supplementation with either wheat bran $(3.75 \%, 7.5 \%)$, barley $(3.75 \%, 7.5 \%)$, or $1 \%$ vegetal oils (sunflower or olive oil) improved, but showed no significant differences on mycelial growth $\mathrm{BE}$ and productivity on sunflower seed hull based substrate containing $7.5 \%$ wheat bran $(\mathrm{BE}=48.3 \%$, productivity $=1.6 \% /$ day $)$ were significantly greater than those obtained on sunflower seed hull substrate $(\mathrm{BE}=40.7 \%$, productivity $=1.1 \% /$ day) .

Whey (milk and cheese-processing) is one of the main dairy industry waste. Milk whey and starch grits have been studied as substrate (submerged conditions) for the production of several strains of G. applanatum and G. lucidum. Micro morphological characteristics of vegetative mycelia, biomass yield and exopolysaccharides were investigated. Nutrient medium with milk whey was optimal for biomass growth and synthesis of polysaccharides for investigated cultures. Maximal content of biomass $(17.2 \pm 0.1 \mathrm{~g} / \mathrm{l})$ was produced by $G$. applanatum on the 11th day of cultivation, G. lucidum $-29.6 \mathrm{~g} / \mathrm{l}$ on then 5 day. On the 11th day of growth the highest amounts of exopolysaccharides in $G$ lucidum was $10.0 \mathrm{~g} / \mathrm{l}$ and in G. applanatum $-9.1 \mathrm{~g} / \mathrm{l}$ (Krupodorova, 2011). A medicinal mushroom, Phellinus linteus, was successfully cultivated using a cheese-processing waste, whey, and the optimal utilization conditions for the maximum mycelial growth rate was also estimated through solid-state cultivation experiments. The results proved a good potential of whey to serve as an alternative growth medium for cultivating $P$. linteus mycelia. The maximum mycelia growth rate was redacted to be $2.80 \mathrm{~mm} /$ day (Lee et al., 2011).

The world coffee production increasing rapidly and, consequently, the husk amount as this production waste. Coffee industry wastes: coffee cherry husk, coffee parchment husk, coffee silver skin, coffee spent wastes, coffee dried leaves with and without supplementation of agricultural wastes such as wheat bran were used for cultivation of $P$. florida. When these substrates were used individually, the mushrooms yield was very low. Among individual substrates, highest yield was observed with coffee charry husk. The best yield $(220 \mathrm{~g})$ was observed in combination: coffee parchment husk $(20 \%)+$ coffee cherry husk (20 $\%)+$ coffee silver skin $(20 \%)+$ coffee spent wastes $(20 \%)+$ coffee dried leaves $(10 \%)+$ wheat bran $(10 \%)$ (Murthy and Manonmani, 2008). It has been studied the suitability of coffee husk for cultivation of $P$. ostreatus after compositing with different main substrate combinations. Composting of coffee waste (husk) was conducted with cow dung, poultry manure and bone meal in the ratio of 3:1. The highest yield $(192.3 \mathrm{~g})$ and $\mathrm{BE}(21.37 \%)$ was obtained from combination of coffee husk (75\%) and cow dung (25\%) on 20 days composting. Therefore, better yield of Oyster mushroom was obtained after utilization of this cost-effective and cheap agro-waste of coffee husk (Mohammed et al., 2014).

Tea leaves after hot water extraction (to obtain water-soluble components) are still contains nutrients and are interesting as alternative substrate for mushroom cultivation. Tea waste (TW) was investigated as a new supplement for substrate mixtures in G. lucidum cultivation in solid-state fermentation. Sawdust (S) based substrates were supplemented with TW at the various levels (75S:25TW, 80S:20TW, 85S:15TW, and 90S:10TW). The substrate formulations producing highest yield and BE were 80S:20TW (87.98 g/ $\mathrm{kg}$ substrate and $34.90 \%)$ and $75 \mathrm{~S}: 25 \mathrm{TW}(82.30 \mathrm{~g} / \mathrm{kg}$ substrate and $31 \%)$. Yield and BE of substrates containing TW were generally higher than that of the control (80 sawdust : 18 wheat bran : 1 sucrose : $1 \mathrm{CaCO} 3$ ). Nitrogen, potassium, iron, and manganese contents and $\mathrm{C}: \mathrm{N}$ ratios of substrates were strongly correlated with yield. BE showed positive and significant correlations with potassium, iron and manganese. Moisture content, potassium, magnesium, calcium, iron, and zinc contents of the fruiting bodies were affected by both strain and substrate. It was concluded that TW can be used as a supplement for substrate preparation in G. lucidum cultivation (Peksen and Yakupoglu, 2009). Used tea leaves showed 5th-6th result $($ yield $=655.0, \mathrm{BE}=65.5 \%$ ) from 13 substrates for $P$. sajor-caju cultivation (Dehariya and Vyas, 2013). Yang et al. (2015) studied Oyster mushroom cultivation using tea waste as substrate. Substrate containing $40 \%$ $60 \%$ of tea waste obtained the highest yield.

Several studies devoted to the utilization by mushrooms of waste products of traditional Korean and Mexican beverages. Mycelia of L. edodes ASI 3046, which is regarded as the most suitable strain for sawdust cultivation, were cultured on six kinds of previous known media and Sikhae Factory Waste (SFW) As the seven kinds of media were applied, a SFW was most excellent in growth. The dried mycelial weight in SFW was almost four times as much as that in the other media. In the flask culture, optimum culture conditions for the mycelial growth were obtained after 13 days of cultivation. SFW must be a remarkable medium for $L$. edodes because of its simple preparation and low cost (Jung et al. 2001). The chemical composition and elemental analysis of Agave salmiana and Agave weberi bagasse (lignocellulosic residues of mexican Mezcal industry) showed a content of $3.70 \%$ and $3.17 \%$ for protein, $5559 \mathrm{mg} / \mathrm{l}$ and $3.23 \mathrm{mg} / \mathrm{l}$ for total reducing sugars, $0.73 \%$ and $0.54 \%$ total nitrogen, $3.46 \%$ and $1.95 \%$ calcium respectively. The BE was $70 \%$ in A. salmiana bagasse and $40 \%$ in $A$. weberi bagasse, the use of these residues for the cultivation of $P$. ostreatus is feasible (Heredia-Solis et al., 2014)

A significant series of investigations (Petre and Petre, 2011; Petre and Petre, 2012; Petre and Petre, 2013a; Petre and Petre, 2013b; Petre and Teodorescu, 2011; Petre and Teodorescu, 2012; Petre et al., 2014) devoted to the utilization of fruit, wine making industry and fruit trees wastes. The screening the optimal biotechnology of medicinal mushroom cultivation from the solid-state fermentation and the submerged one by using different kinds of wastes coming from cereal crop processing as well as the agro-food industry is the aim of Petre and Teodorescu (2011) study. The both fermentation technologies were tested through the controlled cultivation of the medicinal mushrooms $G$. lucidum and $L$. edodes on different growing substrates made of cereal, fruit and vegetable wastes. Among the five nitrogen sources examined, wheat bran was the most efficient upon the mycelia growing and fungal biomass production of $L$. edodes and $P$. ostreatus, at $35-40 \mathrm{~g} \%$ fresh fungal biomass weight, closely followed by malt extract at $25-30 \mathrm{~g} \%$. The best mineral source was $\mathrm{CaCO}_{3}$ that yielded the optimal mycelia growing as well as fungal biomass production at $28-32 \mathrm{~g} \%$. The final fruit body production by the two mushroom species was registered between $1.5-2.8 \mathrm{~kg}$ per $10 \mathrm{~kg}$ of solid composts made from winery wastes. The biotechnological controlled cultivation of edible mushrooms $L$. edodes and $P$. ostreatus was tested (Petre and Petre, 2013b) through the submerged fermentation of different fruit wastes from organic horticulture that provided a fast growth as well as high biomass productivity of investigated strains in comparison with the sample. All culture media used in experiments were prepared from different sorts of organic fruit wastes such as juice and pulps, resulted from the industrial processing of apples, pears and plums. The submerged fermentation was carried out inside the culture vessel of an automatic laboratory-scale bioreactor. The microbial strains of $\quad B$. subtilis and $P$. ostreatus were used in pairs as well as separately to compare the efficiency of their biological potential in utilization of fruit wastes into protein biomass (Petre et al., 2014). These strains were tested both in monocultures and co-cultures for growing on two variants of culture substrates made of apple and plum wastes mixed with cereal wastes. The optimal temperatures for both bacteria and mycelia cultures to produce microbial biomass through controlled submerged fermentation as mono- and co-cultures, were registered between $23-25^{\circ} \mathrm{C}$, corresponding to initial $\mathrm{pH}$ levels of 4.5-6.0 and the agitation speed was tested in the range of 30-90 rpm. The registered results revealed an increasing of reducing sugars correlated with the significant level of protein content analysed as total nitrogen for the microbial biomass of co-cultures, in comparison with the control samples represented by the monocultures of the same bacterial and fungal species used in experiments.

A new substrate, breadcrumbs, was investigated for biomass accumulation, the $\mathrm{pH}$ of the cultural broth, the formation of primary metabolites such as the proteins and endopolysaccharides of $S$. commune and $T$. versicolor, as well as its utilization efficiency. The results showed that $S$. commune gives more mycelial mass $(23.96 \mathrm{~g} / \mathrm{l})$ and in a shorter period (4 days) than T. versicolor $(15.76 \mathrm{~g} / \mathrm{l})$ (in 5 days). The $\mathrm{pH}$ values changed from the initial 6.1 to 3.6 in $S$. commune cultural broth and to 4.4 in T. versicolor cultural broth. Maximal endopolysaccharide content in the mycelia of $S$. commune and $T$. versicolor were $7.13 \%$ and $6.42 \%$, correspondingly. Crude protein content in S. commune 
mycelium was $18.83 \%$ on the 4th day of cultivation, and $20.03 \%$, in the mycelium of $T$. versicolor, on the 6th day of cultivation (Ivanova et al., 2014).

Three food wastes residues (peas, broad bean, beet pulp) were used in different levels with mung bean straw to prepare mushroom growth media for A. bisporus The total yield was: mung bean straw $(2.56 \mathrm{~kg} / 10 \mathrm{~kg})$, mung bean straw + broad bean $=3: 1(2.51 \mathrm{~kg} / 10 \mathrm{~kg}$ ) (Al Abttan et al., 2005).

The aim of the next study (Yang et al., 2012) was to evaluate the feasibility of adding citrus peel (pomelo, lemon, orange and grapefruit) extracts to enhance the formation of bioactive metabolites in the submerged culture of Antrodia cinnamomea. With the exception of grapefruit, citrus peel extracts tested were proved to be beneficial to mycelial growth and to the production of intracellular polysaccharide. Lemon was the most effective for enhancing bioactive metabolite production. With an addition of $2 \%$ of lemon peel extract, the mycelium biomass concentration and intracellular polysaccharide content rose from $11.96 \mathrm{~g} / \mathrm{L}$ of the control and $123.6 \mathrm{mg} / \mathrm{g}$ to $21.96 \mathrm{~g} / 1$ and $230.8 \mathrm{mg} / \mathrm{g}$, respectively, on day 8 . The production of triterpenoids also increased from 86.7 to $282.9 \mathrm{mg} / \mathrm{l}$.

$P$. ostreatus hypha has been cultivated on the food wastes (rice, cabbage pickles, egg soup, pumpkin, lettuce, seasoned vegetables, instant noodle, bean sprout, egg) extracts with concentrations $10,20,30,40$, and $50 \%$. The initial $\mathrm{pH}$ were set variously with $4,5,6$, and 7 . These were cultured for 9 days at the temperature of $25^{\circ} \mathrm{C}$ and the rotation rate of $120 \mathrm{rpm}$. The result is that the mushroom hypha has been grown best at the concentration of fluid $-30 \%$ and the optimal pH was 5 and 6 (Lim et al., 2009).

Water from matured coconut was evaluated for schizophyllan production (Reyes et al., 2009). Sch. commune ATCC 38548 was used as the test strain. Results of the investigation showed that coconut water could stimulate the growth of Sch. commune with subsequent production of schizophyllan at $7.71 \mathrm{~g} / 1000 \mathrm{ml} 4$ days after incubation which is a day earlier than in the two semi-synthetic media. The basal semi-synthetic and the triple sugar- enriched media yielded $6.69 \mathrm{~g}$ and $3.99 \mathrm{~g}$ of schizophyllan per $1000 \mathrm{ml}$ of the medium, 5 days after incubation, respectively.

The contents of $\mathrm{Ca}, \mathrm{Mg}, \mathrm{Na}$, and $\mathrm{K}$ in fruiting bodies (FB) of $G$. lucidum, L edodes, and Pholiota adipose have been determine in Jo et al., (2013) study. The objectives of this study were to evaluate applicability of food waste compos (FWC) as a substrate for cultivation of $\quad$ G. lucidum, L. edodes, and $P$. adipose. FB yield per substrate in FWC-free controls was $53 \mathrm{~g} / \mathrm{Kg}$ for $G$. lucidum, $270 \mathrm{~g} / \mathrm{kg}$ for $L$. edodes, and $1,430 \mathrm{~g} / \mathrm{Kg}$ for $P$. adipose. Substrates supplemented with FWC showed the highest FB production at FWC content of $10 \%$ for G. lucidum $(64 \mathrm{~g} / \mathrm{Kg}), 13 \%$ for L. edodes $(665 \mathrm{~g} / \mathrm{Kg})$ and $P$. adipose $(2,345 \mathrm{~g} / \mathrm{Kg})$, which were 1.2 2.5 times higher than the values for the controls. $P$. adipose contained higher amounts of mineral elements than the other species. $\mathrm{Ca}, \mathrm{Mg}, \mathrm{Na}$, and $\mathrm{K}$ content in $\mathrm{FB}$ did not show a significant relation to FWC content.

Large amounts of food waste attached to actuality of the search for possible utilization, in this case - by higher fungi. New components of substrates: milk whey, fishery waste, fruit waste, winery wastes, oil industry wastes, and food waste compost are characteristic for the majority of the countries of the word and therefore are promising for their utilization by higher fungi. Utilisation of food wastes using Macromycetes is a perspective direction, oriented to satisfaction of the global demand for food protein, nutritional supplements and natural drugs.

\section{CONCLUSIONS}

The dynamic increase of agricultural production can not keep up even more rapid growth of the world population, but leads to the accumulation of large amounts of waste. Waste management and providing a world population with rich in protein food is two important problems of which the utilization of agro-industrial (agriculture and food industry) waste by higher mushrooms causes the growing interest of researchers around the world. Not all mushrooms are edible, but many of not edible mushrooms exhibit various types of therapeutic activity, and at the same time are capable for wastes biodegradation. More than 150 individual types of wastes have been investigated as alternative substrates alone or in various compositions (more than 450 substrates) for cultivation of 52 higher mushroom species (about 100 strains) as evidenced by the results of more than 130 considered in the review scientific publications. All waste is used as a basis for substrates and supplements thereto, are characteristic of the respective continen and region of the world. Alternative substrates will be an integral part for the waste management technology.

Majority of mushrooms listed in the review are wood-decay one's, so the basis of most substrates is lignocellulosic feed stocks (different kinds of sawdust, woodchips, straw, grasses, hulls, etc.). Extremely difficult to determine the regularities that affect the morphological parameters, yield and biochemica composition of different mushrooms, depending on the qualitative and chemica composition of the substrate. Good results are obtained with the combined substrates. Publications containing biochemical studies of substrates and fung confirm that fungi are grown on unconventional substrates rich in biologically active substances, provide a rich biochemical composition of fungi compared with conventional substrates (sawdust, straw, etc.).
The disadvantage of many publications is the lack of mention of examined fungi strains, whereas studies of various strains of the same fungus on the same substrate show different results.

A very important problem escapes the attention of researchers. Most agricultura wastes (various kinds of sawdust, straw, leaves, grasses, etc.) contain toxic substances which can be accumulated by mushrooms, primarily - heavy metals, herbicides, pesticides, the amount of which in grown mushrooms is not determines. Food waste is most often free from this drawback, as the food raw material supplied according to regulatory documents, including the safety performance.

The prospect of the study of agricultural residues utilization by higher mushrooms consists in the investigations of: productivity, biological efficiency of the process, morphological and biochemical indices of cultivated mushrooms, depending on the biochemical parameters of substrates and the process conditions; safety of cultivated mushrooms.

\section{REFERENCES}

Abd Razak, D. L., Abdullah, N., Johari, N. M. K. \& Sabaratnam, V. (2013). Comparative study of mycelia growth and sporophore yield of Auricularia polytricha (Mont.) Sacc on selected palm oilwastes as fruiting substrate. Applied Microbiology \& Biotechnology, 97(7), 3207-3213. http://dx.doi.org/10.1007/s00253-012-4135-8

Adebayo, G. J., Omolara, B. N. \& Toyin, A. E. (2009). Evaluation of yield of Oyster mushroom (Pleurotus pulmonarius) grown on cotton waste and cassava peel. African Journal of Biotechnology, 8, 215-218.

Adedokun, O. M. \& Akuma, A. H. (2013). Maximizing agricultural residues: nutritional properties of straw mushroom on maize husk, waste cotton and plantain leaves. Natural Resources, 4, 534-537. http://dx.doi.org/10.4236/nr.2013.48064

Adedokun, O. M. (2014). Oyster mushroom: Exploration of additional agrowaste substrates in Nigeria. International Journal of Agricultural Research, 9, 55-59. http://dx.doi.org/10.3923/ijar.2014.55.59

Aguilar-Rivera, N., Moran, A. C., Rodríguez Lagunas, D. A. \& Gonzalez, J.M (2012). Production of Pleurotus ostreatus (Oyster mushroom) grown on sugar cane biomass (trash, bagasse and pith). In: S. Andres and N. Baumann (Ed.). Mushrooms: types, properties and nutrition, New York: Nova Science Publishers, pp 77-104.

Ahmed, S. A., Kadam, J. A., Mane, V. P., Patil, S. S. \& Baig, M. M. V. (2009) Biological efficiency and nutritional contents of Pleurotus florida (Mont.) Singer cultivated on different agro-wastes. Nature and Science, 7(1), 44-48.

Akavia, E., Beharav, A., Wasser, S. P. \& Nevo, E. (2009). Disposal of agroindustrial by-products by organic cultivation of the culinary and medicinal mushroom Hypsizygus marmoreus. Waste Management, 29, 1622-1627. http://dx.doi.org/10.1016/j.wasman.2008.10.024

Akinyele, B. J. \& Adetuyi, F. C. (2005). Effect of agrowastes, pH and temperature variation on the growth of Volvariella volvacea. African Journal of Biotechnology, 4, 1390-1395.

Akyüz, M. \& Kirbağ, S. (2010a). Element contents of Pleurotus eryngii (DC. ex Fr.) Quel. var. eryngii grown on some various agro-wastes. Ekoloji, 19(74), 10 14.

Akyüz, M. \& Kirbağ, S. (2010b). Effect of various agro-residues on nutritive value of Pleurotus eryngii (DC. ex Fr.) Quel. var. ferulae Lanzi. Tarim Bilimleri Dergisi-Journal of Agricultural Sciences, 16, 83-88.

Al Abttan, A. A. H., Shareef, H. R. \& Fahad, M. A. (2005). Cultivation of edible mushroom (Agaricus bisporus) in some manufacturing wastes of food. Al-Taqani Journal, 18(3), 1-5.

Alam, N., Amin, R., Khair, A. \& Lee, T. C. (2010). Influence of different supplements on the commercial cultivation of milky white mushroom Mycobiology, 38(3), 184-188. http://dx.doi.org/10.4489/MYCO.2010.38.3.184 Alananbeh, K. M., Bouqellah, N. A. \& Al Kaff, N. S. (2014). Cultivation of oyster mushroom Pleurotus ostreatus on date-palm leaves mixed with other agrowastes in Saudi Arabia. Saudi Journal of Biological Sciences, 21, 616-625. http://dx.doi.org/10.1016/j.sjbs.2014.08.001

Amuneke, E. H., Dike, K. S. \& Ogbulie, J. N. (2011). Cultivation of Pleurotus ostreatus: An edible mushroom from agro base waste products. Journal of Microbiology and Biotechnology Research, 1(3), 1-14.

Ashraf, J., Ali, M. A., Ahmad, W., Ayyub, C. M. \& Shafi, J. (2013). Effect of different substrate supplements on Oyster mushroom (Pleurotus spp.) production. Food Science and Technology, 1(3), 44-51. http://dx.doi.org/10.13189/fst.2013.010302

Ashrafi, R., Mian, M. H., Rahman, M. M. \& Jahiruddin, M. (2014). Recycling of spent mushroom substrate for the production of Oyster mushroom. Research in Biotechnology, 5(2), 13-21.

Bermudez-Savon, R. C., Garcia-Oduardo, N., Serrano-Alberni, M., RodriguezCastro, M. I. \& Mustelier-Valenzuela, I. (2014). Conversion of agroindustrial residues into added-value products by solid state fermentation. Tecnologia Quimica, XXXIV(3), 217-225. 
Boa, E. (2004). Wild edible fungi. A global overview of their use and importance to people. Food and Agriculture Organization of the United Nations (FAO), Rome.

Carreno-Ruiz, S. D., Cappello-garcia, S., Gaitan-Hernandez, R., CifuentesBlanco, J. \& Rosique-Gil, E. (2014). Growth of three tropical edible fungi in culture mediums and agricultural waste. Revista mexicana de ciencias agrícolas 5(8), 1447-1458.

Carvalho, C. S. M., Aguiar, L. V. B., Sales-Campos, C., Almeida Minhoni, M. T. \& Andrade, M. C. N. (2012). Applicability of the use of waste from different banana cultivars for the cultivation of the Oyster mushroom. Brazilian Journal of Microbiology, 43(2), 819-826. http://dx.doi.org/10.1590/S151783822012000200048

Croan, S. C. (2004). Conversion of conifer wastes into edible and medicinal mushrooms. Forest products journal, 54(2), 68-76

D’Annibale, A., Ricci, M., Quaratino, D., Federici, F. \& Fenice, M. (2004). Panus tigrinus efficiently removes phenols, color and organic load from olivemill wastewater. Research in Microbiology, 155(7), 596-603. http://dx.doi.org/10.1016/j.resmic.2004.04.009

Dehariya, P. \& Vyas, D. (2013). Effect of different agro-waste substrates and their combinations on the yield and biological efficiency of Pleurotus sajor-caju. IOSR Journal of Pharmacy and Biological Sciences, 8(3), 60-64.

Dulay, R. M. R., Gagarin, W. S., Abella, E. A., Kalaw, S. P. \& Reyes, R. G (2014). Aseptic cultivation and nutrient compositions of Coprinus comatus (O.F Mull.) Pers. on Pleurotus mushroom spent. Journal of Microbiology and Biotechnology Research, 4(3), 1-7.

Elenwo, E. N. \& Okere, S. E. (2007). Waste re-cycling using edible mushroom cultivation. Journal of Applied Sciences and Environmental Management, 11(3), $153-156$.

EUROPEAN COMMISSION. PRESS RELEASE. (2014). EU research turning food waste into feed. http://europa.eu/rapid/press-release_IP-141165_en.htm. Accessed 5 May 2015.

Fakoya, S., Adejumo, A. F. \& Akinyele, J. B. (2014). Effect of the use of Pycnanthus angolensis and different supplements on yields and on the proximate composition of Pleurotus sajor-caju. Journal of Mycology. http://dx.doi.org/10.1155/2014/642807

Falandysz, J., Szymczyk, K., Ichihashi, H., Bielawski, L., Gucia, M. Frankowska, A. \& Yamasaki, S. I. (2001). ICP/MS and ICP/AES elemental analysis (38 elements) of edible wild mushrooms growing in Poland. Food Additives and Contaminants, 18(6), 503-513. http://dx.doi.org/10.1080/02652030119625

Figlas, D., Gonzalez Matute, R., Delmastro, S. \& Curvetto, N. (2014). Sunflower seed hulls for log system cultivation of Schizophyllum commune. Micología Aplicada International, 26(2), 19-25.

Fomina, V.I., Trukhonovets, V.V., Okhlopkova, N.P., Lesun V.F. (2007). Patent BY No.8910. Minsk: National Center of Intellectual Property of the Republic of Belarus

Gaitán-Hernández, R., Esqueda, M., Gutiérrez, A. \& Beltrán-García, M. (2011) Quantitative changes in the biochemical composition of lignocellulosic residues during the vegetative growth of Lentinula edodes. Brazilian Journal of Microbiology, $\quad 42(1), \quad 30-40 . \quad$ http://dx.doi.org/10.1590/S151783822011000100004

Gizaw, B. (2010). Cultivation and yield performance of Pholiota nameko on different agro industrial wastes. Addis Ababa: Addis Ababa University, 77 p Govindaraju, S., Sangeetha, S. \& Indra Arulselvi, P. (2013). Effect of different agro-wastes on mass production of edible mushroom Pleurotus ostreatus. Indian Journal of Applied Research, 3(6), 33-35.

Harith, N., Abdullah, N., Sabaratnam, V. (2014). Cultivation of Flammulina velutipes mushroom using various agro-residues as a fruiting substrate. Pesquisa Agropecuária Brasileira, 49(3), 181-188. http://dx.doi.org/10.1590/S0100204X2014000300004

Hassan, F. R. H. (2007). Cultivation of the Monkey Head Mushroom (Hericium erinaceus) in Egypt. Journal of Applied Sciences Research, 3(10), 1229-1233.

Hassan, F. R. H. (2011). Utilization of agro and agro-industrial wastes for cultivation of Shiitake (Lentinus edodes) an edible and medicinal mushroom and their drying aspects in Egypt. Research Journal of Agriculture \& Biological Sciences, 7(6), 491-497.

Hassegawa, R. H., Kasuya, M. C. M. \& Vanetti, M. C. D. (2005). Growth and antibacterial activity of Lentinula edodes in liquid media supplemented with agricultural wastes. Electronic Journal of Biotechnology, 8(2). http://dx.doi.org/10.2225/vol8-issue2-fulltext-3

Heredia-Solis, A., Esparza-Ibarra, E., Romero-Bautista, L., Cabral-Arellano, F. \& Banuelos-Valenzuela, R. (2014). Bagazos de Agave salmiana y Agave weber utilizados como sustrato para producir Pleurotus ostreatus. Revista Iberoamericana de Ciencias, 1(5), 103-110.

Ilina, G.V., Ilin, D.J., Ivanov, A.I., Garibova, L.V. (2012). RU Patent No. 2,453,105. Moscow: Federal Service for Intellectual Property of Russian Federation.

Ingale, A. \& Ramteke, A. (2010). Studies on cultivation and biological efficiency of mushrooms grown on different agro-residues. Innovative Romanian Food Biotechnology, 6, 25-28.
Işiloğlu, M., Yilmaz, F., Merdivan, M. (2001). Concentrations of trace elements in wild edible mushrooms. Food Chemistry, 73(2), 169-175. http://dx.doi.org/10.1016/S0308-8146(00)00257-0

Ivanova, T. S., Bisko, N. A., Krupodorova, T. A. \& Barshteyn, V. Yu. (2014) Breadcrumb as a new substrate for Trametes versicolor and Schizophyllum commune submerged cultivation. Korean Journal of Microbiololgy and Biotechnology, 42(1), 67-72. http://dx.doi.org/10.4014/kjmb.1309.09004

Jafarpour, M., Jalalizand, A. \& Eghbalsaied, S. (2011). High fiber media as the most efficient substrates for Pleurotus florida culture. Archives of Biological Sciences, 63(3), 889-895. http://dx.doi.org/10.2298/ABS1103889J

Jo, E.Y., Choi, J. Y., Choi, J. W. \& Ahn, J. H. (2013). Influence of food waste compost on the yield and mineral content of Ganoderma lucidum, Lentinula edodes, and Pholiota adipose fruiting bodies. Mycobiology, 41(4), 210-213. http://dx.doi.org/10.5941/MYCO.2013.41.4.210

Jonathan, S. G., Okon, C. B., Oyelakin, A. O. \& Oluranti, O. O. (2012) Nutritional values of oyster mushroom (Pleurotus ostreatus) (Jacq. Fr.) Kumm cultivated on different agricultural wastes. Nature and Science, 10(9), 186-191.

Jonathan, S. G., Nwokolo, V. M. \& Ekpo, E. N. (2013). Yield performance of Pleurotus pulmonarius (Fries.) Quelet, cultivated on different agro-forest wastes in Nigeria. World Rural Observations, 5(1), 22-30.

Josephine, R. M. (2015). A review on Oyster mushroom (Pleurotus spp) International Journal of Current Research, 7(1), 11225-11227.

Jung, H. H., Lee, J. Y., Kim, G. Y., Park, H. S., Nam, B. H., An, W. G., Lee, S. J. \& Lee, J. D. (2001). Availability of Sikhae factory wastewater as a submerged culture medium for Lentinula edodes. Mycobiology, 29(3), 160-163.

Karuppuraj, V., Chandra Sekarenthiran, S. \& Perumal, K. (2014). Continuous production of Pleurotus florida and Calocybe indica by utilizing locally available lignocellulosic substrates for additional income generation in Rural Area International Journal of Pharmaceutical Sciences Review and Research, 29(1), 196-199.

Khan, A., Tania, M., Amin, S. M. R., Alam, N. \& Uddin, N. (2008). An investigation on the nutritional composition of mushroom (Pleurotus florida) cultivated on different substrates. Bangladesh Journal of Mushroom, 2(2), 17-23. Khan, N. A., Ajmal, M., Javed, N., Ali, M. A., Ul Haq, M. I., Binyamin, R. \& Khan, S. A. (2012). Impact of sawdusts using various woods for effective cultivation of Oyster mushroom. Pakistan Journal of Botany, 44(1), 399-402.

Kirbag, S. \& Akyuz, M. (2008) Evaluation of agricultural wastes for the cultivation of Pleurotus eryngii (DC. ex Fr.) Quel. var. ferulae Lanzi. African Journal of Biotechnology, 7(20), 3660-3664.

Kleofas, V., Sommer, L., Fraatz, M. A., Zorn, H. \& Ruhl, M. (2014). Fruiting body production and aroma profile analysis of Agrocybe aegerita cultivated on different substrates. Natural Resources, 5, 233-240. http://dx.doi.org/10.4236/nr.2014.56022

Krupodorova, T. A. (2011) Growth of Ganoderma applanatum (Pers.) Pat. and G. lucidum (Curtis) P. Karst. and synthesis of polysaccharides in submerged culture. Biotechnologia Acta, 4(6), 60-67 (Ukr).

Krupodorova, T. A. \& Barshteyn, V. Yu. (2012). Alternative substrates for medicinal and edible mushrooms cultivation. Microbiology \& Biotechnology, 1 , 47-56 (Ukr).

Krupodorova, T. A., Barshteyn, V. Yu., Bisko, N. A. \& Ivanova, T. S. (2012), Some macronutrient content in mycelia and culture broth of medicinal mushrooms cultivated on Amaranth flour. International Journal of Medicinal Mushrooms, 14(3), 285-293. http://dx.doi.org/10.1615/IntJMedMushr.v14.i3.50

Krupodorova, T. A., Barshteyn, V. Yu., Peschuk, L. V., Haschuk, O. I. \& Kostenko, E. E. (2014a). Pleurotus ostreatus (Jacq.) Kumm. cultivation on agriculture wastes. Biotechnoljgia Acta, 7(4), 92-99 (Ukr).

Krupodorova, T. A., Rybalko, S. L. \& Barshteyn, V. Yu. (2014b). Antivira activity of Basidiomycete mycelia against influenza type A (serotype H1N1) and herpes simplex virus type 2 in cell culture. Virologica Sinica, 29(5), 284-290. http://dx.doi.org/10.1007/s12250-014-3486-y

Kulshreshtha, S., Mathur, N. \& Bhatnagar, P. (2014). Mushroom as a product and their role in Mycoremediation. AMB Express. http://dx.doi.org/10.1186/s13568014-0029-8

Kumari, D. \& Achal, V. (2008). Effect of different substrates on the production and non-enzymatic antioxidant activity of Pleurotus ostreatus (Oyster mushroom). Life Science Journal, 5(3), 73-76.

Lakhtar, H., Ismaili-Alaoui, M., Philippoussis, A., Perraud-Gaime, I. \& Roussos, S. (2010). Screening of strains of Lentinula edodes grown on model olive mill wastewater in solid and liquid state culture for polyphenol biodegradation International Biodeterioration \& Biodegradation, 64(3), 167-172 http://dx.doi.org/10.1016/j.ibiod.2009.10.006

Lakshmi, S. S. (2013). In vivo utilization of seafood processing wastes for cultivation of the medicinal mushroom (Ganoderma lucidum) using agroindustrial waste. Asian Journal of Pharmaceutical and Clinical Research, 6(4), 51-54.

Lakshmi, S. S. \& Sornaraj, R. (2014). Utilization of seafood processing wastes for cultivation of the edible mushroom Pleurotus flabellatus. African Journal of Biotechnology, 13(17), 1779-1785. http://dx.doi.org/10.5897/AJB2013.13139 
Lakshmipathy, G., Jayakumar, A., Abhilash, M. \& Prema Raj, S. (2012). Optimization of growth parameters for increased yield of the edible mushroom Calocybe indica. African Journal of Biotechnology, 11(11), 7701-7710. http://dx.doi.org/10.5897/AJB11.2874

Lechner, B. E. \& Papinutti, V. L. (2006). Production of lignocellulosic enzymes during growth and fruiting of the edible fungus Lentinus tigrinus on wheat straw. $\begin{array}{lll}\text { Process } \quad \text { Biochemistry, } & \text { 41(3), } & \text { 594-598. }\end{array}$ http://dx.doi.org/10.1016/j.procbio.2005.08.004

Lechner, B. E. \& Monaldi, S. (2011). Utilization of garlic and maize wastes supplemented with olive mill waste water for Pleurotus ostreatus cultivation. Revista mexicana de micología, 34, 17-22.

Lee, C., Lee, S., Cho, K. J., Hwang, S. (2011). Mycelial cultivation of Phellinus linteus using cheese-processing waste and optimization of bioconversion conditions. Biodegradation, 22(1), 103-110. http://dx.doi.org/10.1007/s10532010-9380-x

Lim, J. S., Lee, S. J. \& Lee, E. Y. (2009). Optimal Growth Condition of Pleurotus ostreatus Cultured in the Foodwastes Extracts. Korean Journal of Microbiology and Biotechnology, 37(1), 85-89.

Lipinski, B., Hanson, C., Lomax, J., Kitinoja, L., Waite, R. \& Searchinger, T (2013). Reducing food loss and waste. Working paper, Installment 2 of creating a sustainable food future. Washington, DC: World Resources Institute. Available online at http://www.worldresourcesreport.org.

Magingo, F. S., Oriyo, N. M., Kivaisi, A. K. \& Danell, E. (2004). Cultivation of Oudemansiella tanzanica nom. prov. on agricultural solid wastes in Tanzania Mycologia, 96(2), 197-204.

Mallikarjuna, S. E., Ranjini, A., Haware, D. J., Vijayalakshmi, M. R., Shashirekha, M. N., Rajarathnam, S. (2013). Mineral composition of four edible mushrooms. Journal of Chemistry. http://dx.doi.org/10.1155/2013/805284

Mamiro, D. P. \& Mamiro, P. S. (2011). Yield and mushroom size of Pleurotus ostreatus grown on rice straw basal substrate mixed and supplemented with various crop residues. Journal of Animal \& Plant Sciences, 10(1), 1211-1218.

Mane, V. P., Patil, S. S., Syed, A. A. \& Baig, M. M. V. (2007). Bioconversion of low quality lignocellulosic agricultural waste into edible protein by Pleurotu sajor-caju (Fr.) Singer. Journal of Zhejiang University Science B - Biomedicine \& Biotechnology, 8(10), 745-751. http://dx.doi.org/10.1631/jzus.2007.B0745

Mańkowski, J., Kubacki, A., Kołodziej, J., Pudełko, K. (2011). WO 2,011,145,961. Geneva: World Intellectual Property Organization.

Mansour-Benamar, M., Savoie, J. M. \& Chavant, L. (2013). Valorization of solid olive mill wastes by cultivation of a local strain of edible mushrooms. Comptes Rendus Biologies, 336(8), 407-415. http://dx.doi.org/10.1016/j.crvi.2013.07.004

Meier, E. (2013). Wood allergies and toxicity. The wood database. http://www.wood-database.com/wood-articles/wood-allergies-and-toxicity.

Accessed 13 February 2015

Mohammed, S., Muleta, D., Abate, D. (2014). Bioconversion of coffee husk for oyster mushroom (Pleurotus ostreatus) cultivation in Jimma. International Journal of Microbiology and Immunology Research, 2(6), 75-91.

Mondal, S. R., Rehana, M. J., Noman, M. S. \& Adhikary, S. K. (2010) Comparative study on growth and yield performance of oyster mushroom (Pleurotus florida) on different substrates. Journal of the Bangladesh Agricultural University, 8(2), 213-220.

Moonmoon, M., Uddin, N., Ahmed, S., Shelly, N. J. \& Khan, A. (2010) Cultivation of different strains of king oyster mushroom (Pleurotus eryngii) on saw dust and rice straw in Bangladesh. Saudi Journal of Biological Sciences, 17(4), 341-345. http://dx.doi.org/10.1016/j.sjbs.2010.05.004

Mudakir, I., Hastuti, U. S., Rohman, F. \& Gofur, A. (2014). The Effect of Cocoa Pods Waste as a Growing Media Supplement on Productivity and Nutrient Content of Brown Oyster Mushroom (Pleurotus cystidiosus). Journal of Biology, Agriculture and Healthcare, 4(26), 134-140.

Murthy, P. S. \& Manonmani, H. K. (2008). Bioconversion of coffee industry wastes with white rot fungus Pleurotus florida. Research Journal of Environmental Sciences,

$2(2): 145-150$

http://dx.doi.org/10.3923/rjes.2008.145.150

Muthangya, M., Hashim, S. O., Amana, J. M., Mshandete, A. M. \& Kivaisi, A. K. (2013). Optimization of Pleurotus mushroom cultivation on saline sisal solid waste. World Applied Sciences Journal, 23(9), 1146-1150. http://dx.doi.org/10.5829/idosi.wasj.2013.23.09.912

Nageswaran, M., Gopalakrishnan, A., Ganesan, M., Vedhamurthy, A. \& Selvaganapathy, E. (2003). Evaluation of waterhyacinth and paddy straw waste for culture of oyster mushrooms. Journal of Aquatic Plant Management, 41, 122123

Narayanasamy, P., Suganthavel, P., Sabari, P., Divya, D., Vanchinathan, J. \& Saravana Kumar, M. (2008). Cultivation of mushroom (Pleurotus florida) by using two different agricultural wastes in laboratory condition. The Internet Journal of Microbiology, 7(2). http://ispub.com/IJMB/7/2/12022. Accessed 5 May 2015.

Ng'etich, O. K., Nyamangyoku, O. I., Rono, J. J., Niyokuri, A. N. \& Izamuhaye, J. C. (2013). Relative performance of Oyster mushroom (Pleurotus florida) on agroindustrial and agricultural substrate. International journal of Agronomy and Plant Production, 4(1), 109-116.
Norouzi, A., Peyvast, G. \& Olfati, J. (2008). Oilseed rape straw for cultivation of Oyster mushroom. Maejo International Journal of Science and Technology, 2, 502-507.

Nwokoye, A. I., Kuforiji, O. O. \& Oni, P. I. (2010). Studies on mycelial growth requirements of Pleurotus ostreatus (Fr.) Singer. International Journal of Basic \& Applied Sciences, 10(2), 47-53.

Olufokunbi, J. O. \& Chiejina, N. V. (2010). Impact of substrate on protein content and yield of mushrooms and sclerotia of Pleurotus tuberregium in Nigeria. Mycosphere, 1(4), 293-300.

Onuoha, C. I., Oyibo, G. \& Ebibila, J. (2009). Cultivation of straw mushroom (Volvariella volvacea) using some agro-waste material. Journal of American Science, 5(5), 135-138.

Oseni, T. O., Dube, S. S., Wahome, P. K., Masarirambi, M. T. \& Earnshaw, D. M. (2012). Effect of wheat bran supplement on growth and yield of oyster mushroom (Pleurotus ostreatus) on fermented pine sawdust substrate. Experimental Agriculture \& Horticulture, 1(2), 30-40.

Pani, B. K. (2011). Evaluation of straw of some paddy varieties as substrates for cultivation of milky mushroom (Calocybe indica) in Orissa. Bioscience Discovery, 2(3), 341-342.

Pani, B. K. (2012). Efficacy of an edible tropical fungus, Calocybe indica in the biotransformation of some lingo-cellulosic agro-industrial wastes to protein rich foods. International Journal of Plant, Animal and Environmental Sciences, 2(4), $158-161$.

Parani, K. \& Eyini, M. (2010). Effect of co-fungal treatment on biodegradation of coffee pulp waste in solid state fermentation. Asian Journal of Experimental Biological Sciences, 1(2), 352-359.

Pathmashini, L., Arulnandhy, V. \& Wilson Wijeratnam, R. S. (2008). Cultivation of Oyster mushroom (Pleurotus ostreatus) on sawdust. Ceylon Journal of Science (Biological Sciences), 37(2), 177-182.

Patil, S. S. (2012). Cultivation of Pleurotus sajor-caju on different agro wastes. Science Research Reporter, 2(3), 225-228.

Peksen, A. \& Yakupoglu, G. (2009). Tea waste as a supplement for the cultivation of Ganoderma lucidum. World Journal of Microbiology and Biotechnology, 25(4), 611-618. http://dx.doi.org/10.1007/s11274-008-9931-z

Peng, J. T. (2010). Agro-waste for cultivation of edible mushrooms in Taiwan. Food and Fertilizer Technology Center Publication Database http://www.agnet.org/library.php?func=view \&id=20110725155730\&type_id $=4$. Accessed 5 May 2015 .

Petre, M. \& Petre, V. (2011). Biotechnology for solid-state cultivation of mushrooms on organic wastes from wine making industry. Lucrări știintifice Seria $B-L V$, Horticultură, 55, 711-714.

Petre, M. \& Petre, V. (2012). The semi-solid state cultivation of edible mushrooms on agricultural organic wastes. Scientific Bulletin, Series F, Biotechnologies, XVI, 36-39.

Petre, M. \& Petre, V. (2013a). Environmental biotechnology for bioconversion of agricultural and forestry wastes into nutritive biomass. In M. Petre (Ed.) Environmental Biotechnology - New Approaches and Prospective Applications, InTech Open Access Publisher, pp 3-23.

Petre, V. \& Petre, M. (2013b). Biotechnology for controlled cultivation of edible mushrooms through submerged fermentation of fruit wastes. AgroLife Scientific Journal, J 2(1), 117-120.

Petre, M., Petre, V. \& Rusea, I. (2014). Microbial composting of fruit tree wastes through controlled submerged fermentation. Italian Journal of Agronomy, 9(4), 152-156. http://dx.doi.org/10.4081/ija.2014.610

Petre, M. \& Teodorescu, A. (2011). Medicinal mushrooms cultivation through the solid-state and submerged fermentations of agricultural wastes. Mushroom Biology and Mushroom Products (Proceedings of the 7th International Conference on Mushroom Biology and Mushroom Products (ICMBMP7), Arcachon: INRA, 372-377.

Petre, M. \& Teodorescu, A. (2012). Biotechnology of agricultural wastes recycling through controlled cultivation of mushrooms. In M.Petre (Ed.) Advances in Applied Biotechnology, InTech Open Access Publisher, pp. 3-22.

Philippoussis, A. N. (2009). Production of mushrooms using agro-industrial residues as substrates. In P. Singh nee' Nigam, A. Pandey (eds.). Biotechnology for agro-industrial residues utilisation, Springer, pp. 163-196.

Philippoussis, A., Diamantopoulou, P., Arapoglou, D., Bocari, M. \& Israilides, C. (2004). Agricultural waste utilisation for the production of the medicinal mushroom Lentinula edodes. Protection and Restoration of the Environment VII (Proceedings of the International Conference) Mykonos, http://www.srcosmos.gr/srcosmos/showpub.aspx?aa=7221. Accessed 5 May 2015.

Pokhrel, C. P., Sumikawa, S., Iida, S. \& Ohga, S. (2006). Growth and productivity of Lyophyllum decastes on compost enriched with various supplement. Micología Aplicada International, 18(2), 21-28.

Pokhrel, C. P., Kalyan, N., Budathoki, U. \& Yadav, R. K. P. (2013). Cultivation of Pleurotus sajor-caju using different agricultural residues. International Journal of Agricultural Policy and Research, 1(2), 19-23.

Poppe, J. (2000). Use of agricultural waste materials in the cultivation of mushrooms. In: L. Van Griensven (Ed.). Science and Cultivation of Edible Fungi, Rotterdam: Balkema, pp. 3-23. 
Poppe, J. (2004). Agricultural wastes as substrates for oyster mushroom. Chapter 5. Substrate. In: Mushroom Growers' Handbook 1. Seoul: MushWorld, pp 7586.

Ram, R. C., Kumar, D. S. (2010). Agricultural wastes used as casing mixtures for production of button mushroom. Indian Journal of Scientific Research, 1(1), 2125 .

Ramanathan, G., Vinodhkumar, T., Abinaya Pallavi, T. \& Immanuel Suresh, J. (2013). Evaluation of effect of different substrates on mushroom production and their bioactive potential. International Research Journal of Pharmaceutical \& Applied Sciences, 3(5), 10-15.

Rani, P., Kalyani, N., Prathiba, K. (2008). Evaluation of lignocellulosic wastes for production of edible mushrooms. Applied Biochemistry \& Biotechnology, 151(2-3), 151-159. http://dx.doi.org/10.1007/s12010-008-8162-y

Reina, R., Liers, C., Ocampo, J. A., García-Romera, I. \& Aranda, E. (2013) Solid state fermentation of olive mill residues by wood- and dung-dwelling Agaricomycetes: effects on peroxidase production, biomass development and phenol phytotoxicity, Chemosphere, 93(7), 1406-1412. http://dx.doi.org/10.1016/j.chemosphere.2013.07.006

Reyes, R.G., Graß1, W. \& Rau, U. (2009). Coconut water as a novel culture medium for the biotechnological production of schizophyllan. Journal of Nature Studies, $7(2)$ http://rzv054.rz.tubs.de/Biotech/publications_team/Reyes\%20et\%20al\%202009.pdf Accessed 5 May 2015.

Sagitov, A.O., Yan, Kh., Gosupin, Madzhuga, G.S. (2006). Patent KZ No.28780 Almaty: Department of Intellectual Property Rights of the Ministry of Justice of the Republic of Kazakhstan.

Sagitov, A.O., Yan, Kh., Gosupin, Madzhuga, G.S. (2006). Patent KZ No.28781. Almaty: Department of Intellectual Property Rights of the Ministry of Justice of the Republic of Kazakhstan.

Samuel, A. A. \& Eugene, T. L. (2012). Growth performance and yield of oyster mushroom (Pleurotus ostreatus) on different substrates composition in Buea South West Cameroon. Science Journal of Biochemistry. http://dx.doi.org/10.7237/sjbch/139

Saratale, G. D., Kshirsagar, S. D., Sampange, V. T., Saratale, R. G., Oh, S. E., Govindwar, S. P. \& Oh, M. K. (2014). Cellulolytic enzymes production by utilizing agricultural wastes under solid state fermentation and its application for biohydrogen production. Applied Biochemistry and Biotechnology, 174(8), 28012817. http://dx.doi.org/10.1007/s12010-014-1227-1

Sharma, S. R., Yadav, K. P. \& Pokhrel, C. P. (2013). Growth and yield of oyster mushroom (Pleurotus ostreatus) on different substrates. Journal on New Biological Reports, 2(1), 3-8.

Singh, M. P. \& Singh, V. K. (2011). Yield performance and nutritional analysis of Pleurotus citrinopileatus on different agrowastes and vegetable wastes Proceedings of the 7th International Conference on Mushroom Biology and Mushroom Products (ICMBMP7), pp 385-392.

Stamets, P. \& Chilton, J. S. (1983). The mushroom cultivator. A Practical Guide to Growing Mushrooms at Home. Washington: Agarikon Press.

Stanley, H. O., Umolo, E. A. \& Stanley, C. N. (2011). Cultivation of oyste mushroom (Pleurotus pulmonarius) on amended corncob substrate. Agriculture and Biology Journal of North America, 2, 1336-1339. http://dx.doi.org/10.5251/abjna.2011.2.10.1336.1339

Stanley, H. O. \& Odu, N. N. (2012). Cultivation of oyster mushroom (Pleurotus tuber-regium) on selected organic wastes. International Journal of Advanced Biotechnology Research, 2(3), 446-448.

Taskin, M., Erdal, S. \& Genisel, M. (2011). Biomass and exopolysaccharide production by Morchella esculenta in submerged culture using the extract from waste loquat (Eriobotrya japonica L.) kernels. Journal of Food Processing and Preservation, 35(5), 623-630. http://dx.doi.org/10.1111/j.17454549.2010.00510.x

Taskin, M., Ozkan, B., Atici, O. \& Aydogan, M. N. (2012). Utilization of chicken feather hydrolysate as a novel fermentation substrate for production of exopolysaccharide and mycelial biomass from edible mushroom Morchella esculenta. International Journal of Food Sciences and Nutrition, 63(5), 597-602. http://dx.doi.org/10.3109/09637486.2011.640309

Teplyakova, T. V., Psurtseva, N. V., Kosogova, T. A., Mazurkova, N. A., Khanin, V. A. \& Vlasenko, V. A. (2012). Antiviral activity of Polyporoid mushrooms (higher Basidiomycetes) from Altai Mountains (Russia) International Journal of Medicinal Mushrooms, 14(1), 37-45 http://dx.doi.org/10.1615/IntJMedMushr.v14.i1.40

Thongklang, N., Sysouphanthong, P., Callac, P., Hyde, K. D. (2014). First cultivation of Agaricus flocculosipes and a novel Thai strain of A. subrufescens Mycosphere, 5(6), 814-820. http://dx.doi.org/10.5943/mycosphere/5/6/11

Tripathy, A., Sahoo, T. K. \& Begera, S. R. (2011). Yield evaluation of paddy straw mushrooms (Volvariella spp.) on various lignocellulosic wastes. Botany Research International, 4(2), 19-24.

Ukoima, H. N., Ogbonnaya, L. O., Arikpo, G. E. \& Ikpe, F. N. (2009) Cultivation of mushroom (Volvariella volvacea) on various farm wastes in Obubra Local government of Cross River State, Nigeria. Pakistan Journal of Nutrition, 8(7), 1059-1061.
Ul Haq, I., Aslam Khan, M. \& Ul Haq, M. I. (2011). Proximate analysis of different agricultural wastes used for the cultivation of Volvariella volvacea. Pakistan Journal of Phytopathology, 23(2), 148-151.

Vijaykumar, G., John, P. \& Ganesh, K. (2014). Selection of different substrates for the cultivation of milky mushroom (Calocybe indica P \& C). Indian Journal of Traditional Knowledge, 13(2), 434-436.

Wang, J. H., Wang, Y. F., Sun, J. X., Shi, L., Liu, Z. T. \& Zhao, Y.T. (2013).

Effects of different proportion of waste material of Auricularia auricula on the mycelium growth of five edible fungi. Northern Horticulture, 4, 156-158.

Wasser, S.P., Bilay, V.T. (2006). U.S. Patent No.7,043,874.Washington, DC: U.S. Patent and Trademark Office.

Yang, D., Liang, J., Wang, Y., Sun, F., Tao, H., Xu, Q., Zhang, L., Zhang, Z., Ho, C. T. \& Wan, X. (2015). Tea waste: an effective and economic substrate for Oyster mushroom cultivation. The Journal of the Science of Food and Agriculture. http://dx.doi.org/10.1002/jsfa.7140

Yang, F. C., Ma, T. W. \& Chuang, Y. T. (2012). Medium modification to enhance the formation of bioactive metabolites in shake flask cultures of Antrodia cinnamomea by adding citrus peel extract. Bioprocess and Biosystems Engineering, 35(8), 1251-1258. http://dx.doi.org/10.1007/s00449-012-0712-6

Yang, W. J., Guo, F. L. \& Wan, Z. J. (2013). Yield and size of oyster mushroom grown on rice/wheat straw basal substrate supplemented with cotton seed hull. Saudi Journal of Biological Sciences, 20(4), 333-338. http://dx.doi.org/10.1016/j.sjbs.2013.02.006

Zervakis, G. I., Koutrotsios, G. \& Katsaris, P. (2013). Composted versus raw olive mill waste as substrates for the production of medicinal mushrooms: An assessment of selected cultivation and quality parameters. BioMed Research International. http://dx.doi.org/10.1155/2013/546830 